\title{
Comparing Securitized and Balance Sheet Loans: Size Matters*
}

\author{
Andra Ghent and Rossen Valkanov ${ }^{\dagger}$
}

April 14, 2015

We assemble a unique dataset of commercial mortgages with information on loan characteristics at origination and subsequent performance. The most significant difference between securitized and balance sheet loans is the size of the loan. The loans in the highest loan size decile have a $43 \%$ percent chance of securitization whereas the ones in the lowest decile have only a $1 \%$ chance. This result is consistent with diversification being a key motivation for securitization. We also find that loans that require substantial monitoring are less likely to be securitized. Finally, securitized loans get resolved less quickly after defaulting.

JEL classification: G21, G23, G20.

Keywords: Securitization; Commercial Mortgage-Backed Securities (CMBSs); Structured finance.

\footnotetext{
${ }^{*}$ We have benefited from comments from an anonymous referee, Wayne Archer, Jennifer Dlugosz, Joey Engelberg, Karsten Hansen, Mike Hertzel, Dwight Jaffee, Lubo Litov, Chris Parsons, Marti Subrahmanyan, Allan Timmermann, Walter Torous as well as seminar participants at Arizona State University, BEROC's (Belarussian Economic Research and Outreach Center) Third Annual International Economics Conference, the European Finance Association (EFA) annual meeting, the Federal Reserve Bank of San Francisco, the FIRS annual meeting, the FSU/UF Symposium, the University of California (Berkeley), the University of Oklahoma, the University of Vienna, and the University of Wisconsin (Madison). A previous version of this paper circulated under the title "Advantages and Disadvantages of Securitization: Evidence from Commercial Mortgages". We are extremely grateful to Real Capital Analytics for providing us with our data. We also thank TREPP for providing us with academic pricing. We thank Yue Cao and Sean Flynn for excellent research assistance.

${ }^{\dagger}$ Ghent: Finance Department, Arizona State University; aghent@asu.edu. Valkanov: Finance Department, University of California, San Diego; rvalkanov@ucsd.edu.
} 


\section{Introduction}

Securitization offers lenders important benefits, such as liquidity and risk-sharing, relative to the alternative of holding individual loans on the balance sheets. Not surprisingly, from the early 1990s to 2007, it had become the usual financing structure for residential mortgages and was common in the market for corporate loans, credit card receivables, auto loans, and commercial mortgages. In the wake of the 2007 financial crisis, however, securitization has come under scrutiny in regulatory circles and academic articles. ${ }^{1}$ Although it is not an entirely new form of financing ${ }^{2}$, much less is known about securitized lending than the more traditional model in which a lender retains the asset on its balance sheet. Given the prevalence of securitization before the financial crisis, and its anemic recovery since, it is important to understand how securitized lending differs from balance sheet lending. Namely, are securitized loans different from balance sheet loans in their characteristics and risk profile? If so, what do these differences suggest about the benefits and risks associated with securitization and the fundamental motives for securitization?

In this paper, we study differences between securitized and balance sheet lending using data from the commercial mortgage market. ${ }^{3}$ We assemble and analyze a unique dataset that combines loans held on lenders' balance sheets (henceforth balance sheet loans) and securitized loans on commercial properties (loans packaged into commercial mortgage backed securities, or CMBS) from a large number of lenders in four markets.

\footnotetext{
${ }^{1}$ Several aspects of securitization were explicitly addressed in recent financial legislation. Subtitle D of the Dodd-Frank Act, passed by Congress in 2009 and titled "Improvements to the Asset-Backed Securitization Process," sets new policies on securitization.

${ }^{2}$ Frehen, Rouwenhorst, and Goetzmann (2012) describe the role of securitization in early American land speculation. Snowden (2010) and Riddiough and Thompson (2011) provide good histories of securitization episodes in the U.S. in the 19th century.

${ }^{3}$ We use the term balance sheet loan rather than portfolio loan to refer to non-securitized loans to avoid confusion. The term portfolio loan in the commercial mortgage market is sometimes used to refer to multi-property, as opposed to single-property, loans rather than to indicate a non-securitized mortgage. All of our loans are single-property loans.
} 
Ours is the first paper to construct such a dataset. Most of the empirical work on securitization focuses on residential mortgages, which is understandable given the recent turmoil in that market. However, it is unclear whether the conclusions drawn from the residential mortgage market are applicable to other asset classes and, if so, to what extent. Unlike residential mortgages, commercial loans are typically very large in terms of the market value of the asset that is being financed and the absolute value of the loan. For instance, in our dataset, the largest loan is for $\$ 1.9$ billion for a commercial development in Manhattan. The size of such loans makes it more likely that the risk-sharing incentives for securitization will be apparent.

Consistent with lenders using securitization to reduce their exposure to idiosyncratic risk, we find that the main difference between securitized loans and loans that are held on lenders' balance sheets is size. It is well established that the majority of price risk in real estate markets is idiosyncratic (see, e.g., Case and Shiller (1989)) rather than national or even city-specific. Although securitization of residential mortgages has important benefits, such as mitigating the impact of bank funding shocks on the availability of residential mortgages (Loutskina and Strahan (2009) and Loutskina (2011)), the small size of residential mortgages makes it easy for lenders to diversify the idiosyncratic risk in their residential mortgage portfolio. In contrast, a lender that chooses to hold a large commercial loan on its balance sheet is exposed to substantial idiosyncratic risk.

One can conjecture that the relationship between size and securitization is solely driven by a fixed cost of securitizing a given loan. If this were the case, we would expect to observe securitization only beyond some size threshold and the size effect would be non-linear. To consider this possibility, we group loans into size deciles and find that the likelihood of securitization is monotonically increasing in size and is close to linear. After controlling for other observable loan characteristics, the loans in the 
top decile sorted by loan amount have a $43 \%$ chance of being securitized while less than $2 \%$ of loans in the bottom decile get securitized. Although there are fixed costs of securitization, these costs are at the security level (e.g., hiring underwriters, producing prospectuses) rather than at the loan level. The loan-level cost of securitization is primarily the loan servicing cost which is usually a percentage of the balance of the loan rather than a fixed fee. It is also important to bear in mind that many much smaller loans (e.g., residential mortgages and auto loans) are routinely securitized.

The higher likelihood of securitizing larger loans might be solely due to the fact that they are riskier. For instance, certain borrowers may take on riskier loans which may also be both larger and more likely to be securitized. To explore this possibility, we include borrower fixed effects in a subsample that includes only borrowers with multiple loans. The relationship between loan size and securitization remains after we control for borrower fixed effects. As such, the relationship between size and the likelihood of securitization is not due to unobserved borrower heterogeneity.

We study the selection into securitization using both a reduced form approach that factors in only ex ante information about the loan's characteristics as well as a structural model in which the risk of the loan may influence whether it is securitized. The structural model, while quite simple, distinguishes between selection into securitization based on risk and any causal effect securitization may have on loan performance. The relationship between loan size and securitization is similar in both the reduced form and structural models. We find little evidence that loans selected for securitization are of lower quality in the sense of carrying greater distress risk. It is possible that the reason for the lack of adverse selection in the CMBS market is because the market already incorporates features designed to mitigate adverse selection, such as the loan originator retaining the bottom portion of the loan (see Hartman-Glaser, Piskorski, and Tchistyi, 2012), rather than a lack of potential for 
adverse selection.

We find some evidence of agency issues in the CMBS market, however. Perhaps the most concerning finding is that defaults on CMBS loans are much less likely to get resolved, in the sense of the underlying asset having been disposed of, by the end of our sample. The differences in the resolution of CMBS and balance sheet loans persist after we control for the size of the loan, when the loan was originated, when the loan defaulted, and the market in which it defaulted. After conditioning on these characteristics, we find that defaulted CMBS loans are $19 \%$ less likely to be resolved than defaulted balance sheet loans. Our definition of default is also a conservative one due to our requirement that the same indicator of default is observable for both balance sheet and securitized loans. There may be additional agency issues for securitized mortgages at earlier stages of delinquency that we do not observe. Moreover, in our sample, loans that require substantial monitoring on the part of the lender, development and redevelopment loans in our context, are much less likely to be securitized.

The advantages of using data from the commercial mortgage market to study securitization go beyond the size of commercial mortgages. First, and most importantly, a key advantage of testing for risk-sharing using data from the commercial mortgage market is that, with the exception of loans on multifamily housing, commercial mortgages are securitized without the presence of GSEs that distort incentives. The pervasive influence of the GSEs may make it difficult to extrapolate findings from the residential mortgage market to asset classes with different institutional structures. In particular, because the GSEs absorb the credit risk of the loans they securitize, investors in the agency MBS market bear only the credit risk that the GSEs themselves will not honor their guarantees. It is thus difficult to isolate the securitization benefits from the ability to simply eliminate credit risk using data from the residential 
mortgage market.

Second, regulators often rely on data from CMBS loans, rather than internal data, to assess the health of banks' commercial lending portfolios. However, the existing literature contains no information regarding how securitized commercial real estate loans differ from loans held on banks' balance sheets. Our results will help regulators and market participants understand when CMBS data can be useful in evaluating balance sheet lenders' portfolios. Our findings also provide guidance regarding the adjustments that analysts need to make when using data from CMBS loans to assess lenders' balance sheets. ${ }^{4}$

To our knowledge, ours is the first paper to show concrete evidence of a diversification motive for securitization. We are also the first paper to use a comprehensive data set of balance sheet and securitized commercial mortgages. Perhaps the most closely related paper to ours is An, Deng, and Gabriel (2011) who suggest that the decline of the balance sheet CMBS market (i.e., mortgages originated as balance sheet loans) owes to adverse selection from balance sheet originators into the CMBS market. Their methodology and empirical results rely exclusively on CMBS loans, whereas our data set includes both balance sheet and securitized loans. They also look at an earlier sample period of 1994-2000.

The remainder of the paper proceeds as follows. Section 2 describes our data set. In Section 3, we present a predictive analysis of whether a loan is securitized. In Section 4, we present a simple econometric model to test for adverse selection. Section 5 concludes.

\footnotetext{
${ }^{4}$ See, for example, the presentations from regulators made at the Federal Reserve Bank of Boston Stress Testing Model Symposium. The presentations are available at http://www.bos.frb.org/StressTest2012/index.htm. We thank Nancy Wallace for bringing this issue to our attention.
} 


\section{Data}

We construct our data set from transactions of office property in the metropolitan statistical areas (MSAs) of Boston, Las Vegas, Los Angeles, and New York. The data was provided by Real Capital Analytics (RCA), a leading provider of commercial property and mortgage data. We use two of RCA's databases in this study. The first contains information on the properties financed by mortgages. The other product is RCA's troubled asset database which tracks distressed mortgages. We link the two datasets using the address of the property. All mortgages in our sample are singleproperty purchase mortgages (i.e., they are used to purchase a property rather than to refinance an existing loan) originated between January 1st, 2005 and May 1st, $2012 .^{5}$ The start of the sample coincides with the first date that RCA has comprehensive data on balance sheet mortgages. RCA specializes in transactions on property values of $\$ 2.5$ million and above so we have comprehensive data for properties above this threshold.

The four cities for which data is available have diverse commercial real estate markets. New York (including Manhattan) is consistently the largest office property market by a considerable margin. Los Angeles was the third largest office property market, as measured by sales volume, in 2007, the second largest in 2008, but had fallen to seventh place in 2010. Boston was not a large office market during the boom years of 2005-2007, but it fared well throughout the downturn. Las Vegas, although a relatively small portion of the national office market, experienced a disproportionate share of distress. The cities in our sample represent between $30 \%$ and $40 \%$ of the national office market based on the dollar amount of sales transaction and approxi-

\footnotetext{
${ }^{5}$ While we have detailed information on refinancings for securitized mortgages, such data is not comprehensive for balance sheet mortgages. To prevent a potential selection bias, we focus on purchase mortgages.
} 
mately $25 \%$ of the national office market based on the number of sales. ${ }^{6}$ They have differing shares of the national office property market over our sample and each one has experienced a somewhat different real estate cycle. Nevertheless, it remains the case that our data is not fully representative of the national real estate market and, in particular, has few observations from smaller cities in the US heartland.

Securitized versus Balance Sheet Loans: RCA collects data shortly after a commercial real estate transaction takes place. For transactions involving a loan, information about the financing is also available. If the loan is known to be from a conduit lender-a lender who originates mortgages with the sole purpose of securitizing them as soon as they are issued-RCA enters details of the security the loan will be packaged into. Many large loans that exceed industry norms for conduit deals are also originated into CMBS. CMBS deals that include such large loans are typically referred to as "fusion" deals or "conduit/fusion" deals if the deal contains large loans as well as smaller conduit loans. It is also possible that a single loan may be originated as a CMBS deal. These loans are readily categorized as CMBS. The remaining mortgages are either balance sheet loans or were securitized at a date after origination. In principle, mortgages can be securitized at any point after issuance but, in practice, the overwhelming majority of commercial real estate loans are securitized at origination or not at all. See An, Deng, and Gabriel (2011) for a similar finding from a sample ending in 2001.

Nevertheless, to prevent any misclassification of loans, we run a second check to verify whether a loan has been securitized at some point after issuance. We do so using the TREPP database, which contains comprehensive loan-level data for securitized mortgages in the US. The merged RCA-TREPP data allows us to ascertain that loans we classify as balance sheet do not end up being securitized at a later point. After

\footnotetext{
${ }^{6}$ These calculations are based on RCA aggregate sales data.
} 
cross-referencing the portfolio loans in the RCA data with the TREPP data, we find that less than $3 \%$ of the mortgages that RCA codes as balance sheet loans are recorded in TREPP (as being securitized) confirming the rarity of non-conduit originations in CMBSs. For this study, a loan is categorized as CMBS if it is classified as securitized in the RCA data or if it is in the TREPP data. We define a dichotomous variable, CMBS, that equals one for securitized loans and zero for balance sheet loans.

Other Variables: The RCA data also contains information on other loan-, property-, and borrower-specific characteristics. For all mortgages, we have the loan amount, the loan to value (LTV) at origination, and the date of origination. ${ }^{7}$ The available property variables are: price at origination, price per square foot, the year the property was built, its square footage, the number of floors, whether the property has multiple buildings, and whether or not it is located in a central business district (CBD). In addition, we know whether the property is located in Boston, Las Vegas, Los Angeles, or New York City.

RCA keeps track of the borrower type, which it sorts into the following categories: Developer/Owner/Operator, Equity Fund, Corporate, REIT, Other/Unknown. The largest category by far is the Developer/Owner/Operator category which RCA defines as a non-traded privately held Development/Property Management/Owner/Operator firm. Regarding the definition of Equity Funds, RCA states the following: Equity Funds are "privately held and guided investment vehicles dedicated to commercial real estate investment. Equity Funds gather and commingle investment funds from investors in other categories and specific funds often focus their investments by location, property type or return profile i.e., opportunistic or value-add." RCA defines

\footnotetext{
${ }^{7} \mathrm{As}$ balance sheet loans are not subject to the same disclosure requirements as CMBS loans, we do not have comprehensive data on loan terms for balance-sheet loans. While we do have information on the interest rate, maturity, and other loan terms for the CMBS loans and for some of the balance sheet loans in our sample, there is likely to be a sample bias in the balance sheet loans for which we have such data. As a result, we do not make use of detailed information on loan terms.
} 
corporate borrowers as borrowers who use real estate primarily for corporate use. REITs are defined according to the tax code; we include both public and privately traded REITs under the same category as we have relatively few of each type.

RCA records the name of the lender. For a subset of loans originated by depository US institutions, we obtain the FDIC certificate number from the FDIC's website. We then use the Call Reports to obtain the originator's assets in the quarter the loan is originated. At the time of writing, we did not have lender assets for most loans originated in 2011 or 2012.

Defaults: We classify all loans in our sample as either having defaulted or not having defaulted using indicators of distress that are observable for both securitized and balance sheet loans. We code a loan as having defaulted only if the loan has gone through foreclosure, if a foreclosure has been initiated, or if the borrower has declared bankruptcy. Consequently, the loans we code as having defaulted are quite troubled and almost all of our defaults result in the borrower losing control of the property. Our definition of default also implies that our dating of default is late into distress rather than occurring at an early indicator of distress (e.g., the first missed payment). We use loan amounts at origination to calculate the amount of loans in distress although the figures are very similar if we use RCA's estimate of the outstanding balance at the first indication of distress. Although some of the loans in our sample are partly amortizing, many are development loans which typically have increasing balances over time.

Given our conservative definition of a default, RCA codes many loans as troubled that we do not code as having defaulted. For example, RCA codes a securitized loan that is transferred to the special servicer as troubled while we do not classify such a loan as having defaulted if that is the only indicator of distress. For securitized commercial mortgages, the default process usually begins when the master servicer 
of the deal transfers the loan to a special servicer that is responsible for resolving the delinquency by either modifying or foreclosing on the loan. Ambrose, Sanders, and Yavas (forthcoming) provide details on this process. While a transfer to the special servicer definitely indicates distress, there is no comparable indication of trouble for balance sheet loans in the data since balance sheet commercial loans do not generally have servicers.

Our conservative definition of default means that we do not study the early stages of delinquency including how and why a securitized loan gets transferred to the special servicer. As Gan and Mayer (2007) discuss, there may be substantial differences in the timing of transfer to the special servicer and the distress event depending on the ownership of the various tranches in the security. The borrower itself may also request a transfer to the special servicer even if the loan is not in default. Ambrose, Sanders, and Yavas (forthcoming) also highlight conflicts of interest between the master servicer and the special servicer.

Resolution after Default: Of our defaulted loans, most had not been resolved by the end of our sample in the sense of no longer being a troubled asset on the lender's balance sheet or, for securitized loans, the trust's. This is perhaps not surprising given the extent of the problems in the commercial property market since the loans defaulted. Of the 175 loans we identify as defaulted, 83 had been resolved by the end of our sample. The resolution almost always ends with the borrower losing control of the property: Of the 83 resolutions we observe, only 3 are resolved via a refinancing with no loss to the lender (recovery rate $=100 \%$ ). Twelve loans are resolved via a purchase by another buyer before the foreclosure sale without any loss to the lender (recovery rate $=100 \%$ ) and 3 of the loans are resolved by an assumption of the loan by a new property owner without any loss to the lender (recovery rate $=100 \%)$. Another 59 resolutions are accomplished by a sale of the property either before or after the 
foreclosure sale with the lender taking a loss. We do not have sufficient information to ascertain recovery rates or exactly how the default was resolved for the remaining 6 loans that RCA indicates had been resolved by the end of our sample.

\subsection{Summary Statistics}

Table 1 provides summary statistics of the CMBS variable along with the other characteristics of the loans. There are 1,962 purchase mortgages in the dataset, 19\% of which are CMBS loans (367 observations). The average loan amount is $\$ 32$ million with a large standard deviation $(\$ 88 \mathrm{M})$ and skewness 8.8 . The heterogeneity in loan sizes in commercial deals is significant: The smallest loan in our database is only $\$ 0.2$ million whereas the largest one is $\$ 1.9$ billion (CMBS). The average loan in our data is likely larger than the average US commercial real estate loan because of our inclusion of the expensive property markets of Boston and, especially, NYC. The average loan amounts on property in Boston and NYC are $\$ 33$ and $\$ 50$ million while the respective figures on property in LA and Las Vegas are $\$ 15$ and $\$ 8$ million. Because NYC represents $43 \%$ of our sample, the loan amount is higher than we would likely observe in the universe of commercial mortgages in the United States. This is also reflected in the high price per square foot of $\$ 339$. By comparison, RCA transaction data for $2005-2010$ yields a price per square foot of $\$ 227$. As we control for the MSA in our results, the larger than usual loan size does not drive our results. Nevertheless, in an appendix, we verify the robustness of our main results to the exclusion of loans from NYC.

The average loan-to-value ratio is $75 \%$ with a standard deviation of $46 \%$. We have 194 loans with LTVs above 100\% such as the maximum LTV of $973 \%$ shown in the table. $95 \%$ of the loans with LTVs above $100 \%$ are balance sheet loans. Many 
such loans are development or redevelopment loans wherein the lender provides the borrower with funds to develop the property in addition to funds to purchase the property. We do not have a comprehensive indicator in the data for whether a loan is a construction or development loans. In our benchmark specification, we therefore define a development loan as one with an LTV of $100 \%$ or more. There may be other reasons, such as aggressive underwriting, that a loan may have an LTV of $100 \%$ or more such that our definition of a development loan is imprecise. In the appendix, we therefore investigate the sensitivity of our main results to alternative definitions of a development loan. The alternative definitions use a different LTV threshold or use the borrower's stated intention to define a development loan. Our main results other than the relationship between securitization and development loans are also robust to excluding loans with LTVs above $100 \%$.

We have the origination date of each loan, the mean of which is 2007 for our 20052012 sample. It is important to mention that the commercial real estate market has been affected by the financial crisis of 2008-2009. The entire securitization industry (RMBS, CMBS, CLOs, CDOs, etc.) was frozen during those years as well and is only now slowly recovering. We discuss this episode in detail below, correct for this time variation with year dummies throughout the paper, and conduct various robustness checks.

Regarding property-specific variables, the average price is $\$ 49 \mathrm{M}$ with a minimum price of $\$ 1.60 \mathrm{M}$ and a maximum price of $\$ 2.95$ billion. The price per square foot similarly displays large variation, ranging from $\$ 11$ to $\$ 4,933$, with an average value of $\$ 339$. We observe that $43 \%$ of the properties are in NYC, $39 \%$ are in Los Angeles, while properties in Boston and Las Vegas constitute a modest $14 \%$ and 5\% of our sample. The sample contains fewer loans on NYC property than NYC's share of the office property market in our four cities. This is most likely because NYC property 
investors are larger and thus a larger share of transactions are financed with public debt rather than mortgages (see Giambona, Mello, and Riddiough, 2012).

The most likely borrowers, constituting about $65 \%$ of all commercial mortgages, fall in the Developer/Owner/Operator category. Equity funds, corporations, and REITs follow with about $9 \%, 6 \%$, and $4 \%$ of loans. The remaining $16 \%$ of loans are extended to various other entities or to borrowers of unknown category. Slightly more than half our loans (54\%) are originated by depository U.S. institutions.

The aggregate numbers in Table 1 do not reveal the time-series properties of the data. While most of the analysis will be conducted with the pooled dataset, it is important to highlight two peculiarities of the sample period. First, the number of commercial loans issued dropped precipitously during the financial crisis, from 442 (market value of $\$ 18.7 \mathrm{~B}$ ) in 2007 to 214 (\$4.7B) in 2008 and to 69 (\$1.4B) in 2009. Since then, the market is improving but the 2010-2012 numbers are not near their pre-crisis levels.

Second, the crisis hit the CMBS market particularly hard, resulting in its effective shutdown in 2008 and 2009. The number of CMBS loans plummeted from 110 in 2007 (with a market value of $\$ 77 \mathrm{~B}$ ) to zero in the subsequent two years. While the number of balance sheet loans also declined significantly during this period - by about $36 \%$ between 2007 and 2008, and by about $68 \%$ between 2008 and 2009 - the issuance of commercial mortgages did not come to a standstill. Stanton and Wallace (2012, Table 4) similarly report a collapse in the universe of CMBS loans in TREPP, from 5219 loans in 2007 to 53 loans in 2008. There was a parallel collapse of the private label RMBS market during the financial crisis (see Calem, Covas, and Wu (2013) and Fuster and Vickery (2015)). There has also been a significant decline in the securitization rate of non-mortgage consumer credit. The securitization rate of non-mortgage consumer credit fell from $27 \%$ in 2007 to $2 \%$ in 2011, the lowest rate 
since the Federal Reserve began tracking pools of securitized consumer credit in 1989 (Federal Reserve Board of Governors, 2012).

To illustrate these facts, Figure 1 plots the number of CMBS and balance sheet loans originated each year in our sample. Figure 1 also plots the cumulative number and volume of loans that defaulted in our sample. The first time we observe default of any of the loans in our sample is in 2008. During that year, 15 loans worth a combined $\$ 344$ million defaulted. In 2009, another 44 loans with a combined total balance of $\$ 2.2$ billion entered default, a larger amount than issuance of new loans in 2009. In 2010, another $\$ 2.6$ billion worth of loans entered default. By the end of our sample, $\$ 6.2$ billion worth of loans had entered default. In Figure 2 we plot the Moody's/RCA commercial property price index for office property at the national level. It is a repeat transaction index similar to the Case-Shiller and FHFA home price indices. $^{8}$

To check whether the crisis had a significant effect on the variables of interest, in the second panel of Table 1 we display summary statistics based on loans that were originated during the pre-crisis period of 2005-2007. We observe that pre-crisis, the ratio of CMBS loans was higher $(27 \%)$. We also notice small differences in the average loan amount $(\$ 36 \mathrm{M})$, but most other variables including LTV, price, price per square foot, and other property and borrower characteristics are similar.

\subsection{Comparing CMBS and Balance Sheet Loans}

As a first step in our analysis, we investigate differences between securitized and balance sheet loans. Systematic differences in their characteristics may provide insight behind the economic motivation for securitization and such a comparison has not been

\footnotetext{
${ }^{8}$ The Moody's / RCA office property price indices are not available at the MSA level because there are far fewer office property transactions than residential transactions.
} 
done in the literature. The characteristics that we investigate are all known at loan origination, and are pre-determined with respect to loan performance (i.e., default and loss given default).

In Table 2, we compute the averages of all characteristics in Table 1 for CMBS and balance sheet loans separately. We then conduct univariate comparisons between the means using a t-test of differences in means where the null is that balance sheet loans are not statistically different from CMBS loans. Looking at the loan-specific characteristics, there are substantial differences. The most striking difference is that, unconditionally, securitized loans are more than twice as large as portfolio loans, a difference that is economically meaningful and statistically significant at the 1 percent level. Moreover, securitized mortgages are associated with properties with more square footage, with more floors, and more likely to be comprised of multiple buildings. Securitized loans are less likely to be extended on properties located in a central business district (31\% versus 37\%). As far as geographic differences go, securitized loans are slightly less likely to finance transactions in Los Angeles but more likely to finance transactions in Las Vegas. Properties financed with securitized loans are about nine years younger on average than properties financed with portfolio loans. All of these differences are significant at the 1 percent level. Several important characteristics, such as LTV and price-per-square foot, are remarkably similar between securitized and balance sheet loans.

The average securitized loan in our sample is for $\$ 64$ million. How do our loans compare with loans in the typical US CMBS deal? The average "Conduit / Fusion" US CMBS deal issued over our sample period has an average loan size of $\$ 15.7$ million while the average "Single Asset or Single Borrower" (SASB) US deal has an average loan size of $\$ 375$ million. The average other type of US CMBS deal has an average loan size of $\$ 96$ million. During our sample period, "Conduit / Fusion", SASB, and 
"Other" deals constituted $79 \%, 20 \%$, and $1 \%$ of US CMBS deals issued. The large average size of our securitized loans indicates that many of the loans went into SASB deals. ${ }^{9}$

There are also substantial differences between the types of borrowers that finance themselves with securitized loans rather than with balance sheet loans. While by far the most common type of institution among our borrowers is the Developer/Owner/Operator category, equity funds and REITs are much more likely to use securitized borrowing. Given that REITs often have extensive ties to lenders, it may be surprising that they rely on securitized mortgages. However, many REITs rely on general bank loans or unsecured debt rather than property-specific mortgages such that many of their property purchases will not be financed with a mortgage per se; see Giambona, Mello, and Riddiough (2012) for a discussion of REITs' financing strategies. Corporate borrowers are more likely to rely on balance sheet loans.

The picture that emerges from this comparison is that securitized loans tend to be issued on larger properties - properties with more square footage, more floors, and multiple buildings. Because the purchase of such buildings requires larger mortgages, we find that securitized loans tend to also be significantly larger, in dollar amount. However, we do not find significant differences in price-per-square-foot in the univariate analysis.

\footnotetext{
${ }^{9}$ These statistics come from calculations on all US CMBS deals available on Bloomberg issued 2005Q1-2012Q2 excluding agency deals, Re-REMIC deals, and CDOs. The deal types "Conduit / Fusion" and SASB are classified by Bloomberg. We categorize all other Bloomberg deal types as "Other".
} 


\section{The Characteristics and Performance of CMBS and Balance Sheet Loans}

We model the likelihood of securitizing a commercial loan using variables that are known at the time of loan origination. ${ }^{10}$ In other words, we predict the probability of a loan being securitized, conditional upon its characteristics.

\subsection{The Likelihood of Securitizing and Loan Size}

The fact that there are significant differences between securitized and balance sheet loans suggests that their characteristics might predict whether a loan is securitized. Since many of the loan characteristics that we consider are correlated with one another, we would like to know how to weigh them optimally in predicting the likelihood of securitization.

We model the discrete decision of whether to securitize a loan as an index function. The observable characteristics that influence the decision are captured by a vector $x_{i, t-1}$ and enter linearly into the decision process $Y_{i, t}^{*}$, where

$$
Y_{i, t}^{*}=x_{i, t-1} \beta+u_{i, t}
$$

and $u_{i, t}$ are the unobservable (to the econometrician) characteristics of loan $i$ at time $t$. The loan characteristics in vector $x_{i, t-1}$ have a $t-1$ subscript because they are known before the loan is originated.

While the decision process itself is unobservable, its outcome - whether a loan is

\footnotetext{
${ }^{10}$ This mitigates the possibility of biases that stem from endogeneity and from the fact that, in a static probit estimated from an arbitrary starting date (other than origination), a loan could have been in distress (which is unobserved) several periods before going into default (Shumway (2001)).
} 
securitized - is observable. Hence, we construct a dichotomous variable $C M B S_{i, t}$ which equals one if a loan is securitized and zero otherwise, which is related to $Y_{i, t}^{*}$ as $C M B S_{i, t}=1$, if $Y_{i, t}^{*}>0$ and zero otherwise. Thus, $P\left(C M B S_{i, t}=1\right)=$ $P\left(Y_{i, t}^{*}>0\right)=F\left(x_{i, t-1} \beta\right)$, where $F$ is the symmetric distribution of $u_{i, t}$. We assume that $F($.$) is the normal distribution, denoted by \Phi$, and obtain the probit model

$$
P\left(C M B S_{i, t}=1\right)=\Phi\left(x_{i, t-1} \beta\right) .
$$

In Table 3 , we report estimates of $\beta$, robust standard errors, and marginal probabilities averaged over all observations from estimating (2) for various specifications of $x_{i, t-1}$. We also report the pseudo- $R^{2}$ for each probit. In the specification presented in column 1, the characteristics are the log loan amount, whether the loan is a development or redevelopment loan (LTV $\geq 1$ ), the LTV, price-per-square-foot, a dummy for whether the property is located in a CBD, a dummy for whether the property contains multiple buildings, year of origination dummies, MSA dummies, property age dummies, and dummies for the borrower's institutional type. We use the log transformation of the loan amount to stabilize the variance of the series. In the specification in column 2 , we add a dummy variable for whether the originator is a depository US institution. In column 3, the loan amount is controlled for in deciles rather than continuously to allow for any nonlinearity that might exist between size and the probability of securitization.

The results from the first three columns of Table 3 can be summarized as follows. The size of the loan is statistically significant (at the 1 percent level) in all specifications: larger loans have a higher likelihood of being securitized. Similar results (not displayed) obtain for other proxies for loan size, such as property price, square 
feet, and number of floors. Hence, the importance of loan size as a predictor of the likelihood of securitization is a novel and robust result.

In terms of economic magnitude, the marginal impact of log loan size, evaluated at the mean value of all conditioning variables, results in the probability of securitization increasing by about 9 percentage points. Figure 3 provides a better gauge of the economic importance of loan size on the probability of securitization. Panel A of Figure 3 displays the probability of securitization estimated using coefficients of the nine size deciles from specification (3) of Table 3; Panel B of the figure displays the coefficients themselves. The probability of securitization is calculated for each observation using the coefficients from the probit model and varying only which decile of the loan amount the loan is in. The probabilities shown represent the average likelihood of securitization for each decile using this calculation.

Panel A illustrates that the loans in the lowest two size deciles, i.e., the smallest $20 \%$ of loans, have about a one percent chance of being securitized. As the loan size increases, the probability of securitization also increases in a monotonic fashion. Remarkably, loans in the top decile have a $43 \%$ chance of being securitized. Hence, the difference in the probability of securitizing the largest versus the smallest loans is 42 percentage points.

The strong relationship between loan size and the probability of securitization indicates that risk-sharing is a key reason for securitization in the commercial real estate market. The largest component of risk in property values is idiosyncratic rather than city-specific or national. For example, Case and Shiller (1989) famously documented that, although city-level home prices are highly forecastable, city-level indices are very poor predictors of the price of any particular property. Goetzmann (1993), Deng, Quigley, and Van Order (2000), and Flavin and Yamashita (2002) similarly document the much larger degree of risk at the individual property level than 
at the city or national level. The small size of residential mortgages enables balance sheet lenders to effectively diversify the idiosyncratic risk. However, the large size of commercial loans makes it very difficult for even a large lender to diversify away the idiosyncratic risk of his portfolio. A commercial mortgage lender's key motivation for securitization is thus that it reduces his exposure to large, otherwise difficult to diversify, idiosyncratic risks.

\subsection{Identification of Size Effect Within Borrower}

Although we have good information on the quality of the loan collateral, missing from regression (2) are variables that proxy for the quality (or riskiness) of the borrower. The vast majority of our borrowers are not public companies and therefore we do not have hard information on their credit-worthiness. Furthermore, even if we had financial statements from our borrowers, which would allow us to use key financial metrics like debt service coverage ratios in estimating (2), there remains the possibility of substantial differences in the soft information characteristics of balance sheet and CMBS borrowers. Without additional proxies for borrower risk, it is possible that the relationship we find between loan size and securitization is driven by unobserved borrower heterogeneity rather than loan size in fact driving securitization.

Assuming that the primary unobserved risk is borrower-specific, in Table 4, we estimate equation (2) on the subset of loans for which we can control for borrower risk using borrower fixed effects. The identifying assumption behind this estimation is that the risk of the loan is primarily borrower-specific after controlling for other observable risk factors. Because many of the borrowers in our sample have only one or two loans, introducing borrower fixed effects limits our sample to the subset of loans from repeat borrowers that have at least one securitized and one balance sheet 
loan. Nevertheless, regardless of whether we limit the sample to borrowers with at least 4 loans, at least 5 loans, at least 6 loans, or at least 7 loans, the coefficient on Log Loan Amount remains highly statistically significant in all specifications. The magnitude of the coefficient on loan size in fact increases when we control for borrower heterogeneity.

\subsection{Alternative Explanations of Loan Size}

The monotonicity in the relationship between loan size and the probability of securitization rules out the possibility that fixed costs of securitizing a loan is the main driver behind this finding. Indeed, if there were a large fixed cost of securitizing loans, we would expect to only observe securitization above a certain size threshold rather than a continuously increasing probability of securitization: loans below that size threshold would not be large enough to justify the costs. Furthermore, the institutional structure of the commercial mortgage market also indicates that there is not a significant fixed cost of securitizing a single loan that would drive our finding. First, servicers are paid as a percentage of the loan balance rather than per loan. Second, many much smaller loans, such as residential mortgages and auto loans, are routinely securitized. Although securitization may involve fixed costs, they would occur at the deal level (e.g., hiring a trustee, preparing a prospectus, etc...) rather than at the individual loan level.

In column 2 of Table 3 , we observe that depository US institutions are more likely to originate securitized loans than other institution types. This finding indicates that there may be heterogeneity in the types of loans that various commercial mortgage originators issue. If the originator is not a depository US institution, however, we have very little information about it. Most non-depository originators are not publicly 
listed. To better control for heterogeneity in originators, in columns 4 and 5 we restrict the sample to loans originated by depository US institutions. By thus restricting the sample, we control for the originator's size as well as measure loan size relative the lender's assets. Loan size continues to be a very strong predictor of securitization in the subsample of loans. In terms of economic magnitude, a one standard deviation increase in relative loan size raises the chance that the loan will be securitized by 2.5 percentage points.

Columns 4 and 5 also indicate, however, that large institutions are more likely to originate loans for the securitized market. The estimates in column 4 indicate that a one standard deviation increase in the size of the lender (as measured by its total assets) increases the probability of securitization by seven percentage points, an effect that is significant at the $1 \%$ level.

It seem possible, and consistent with our results in columns 4 and 5, that small originators are, for whatever reason, excluded from the securitization market. This might be because small originators lack relationships with securitization sponsors and depositors, because there are large fixed costs of learning how to originate for the securitized market, or because of other frictions. Furthermore, small originators may originate small loans whereas large originators may primarily originate large loans. It is possible that our finding that larger loans are more likely to be securitized is due to such frictions in the securitization market rather than any diversification motive.

To explore this possibility, in column 6 we restrict the sample to the 10 largest originators in our sample that originate loans for both the balance sheet and securitized market. In the specification reported in column 6 , we are able to include originator fixed effects. These 10 lenders are responsible for more than 500 originations in our sample and each of these lenders originated at least 30 loans. In the sample of these large originators, the size of the loan continues to be the most important determinant 
of securitization. The coefficient on loan size is also similar in magnitude to that found in the other specifications. This result indicates that the effect of size on the likelihood of securitization is not due to differences in access to the securitization market or other frictions.

Development and redevelopment loans are at least 20 percentage points less likely to be securitized than other mortgages. It is possible that some of our loans with high LTVs that are below $100 \%$ are also development loans since commercial mortgages generally allow lower LTVs on non-development loans than residential mortgages. Development loans require substantial monitoring on the part of the lender since the funds are dispersed in increments conditional on each stage of construction being completed to the lender's satisfaction. The incentives to conduct such monitoring are much lower when a lender has a less concentrated interest in the loan (see Diamond (1984)) such as with securitized loans.

\subsection{Sensitivity Analyses}

We conduct several sensitivity analyses of our results regarding the ex-ante differences between balance sheet and CMBS loans. First, we estimate the model using only originations from 2005 to 2007 since there are so few CMBS originations from 2008 onward (see Figure 1); these results are available in the appendix. Second, we estimate the index model using a logit rather than a probit. Finally, we estimate the model after dropping all loans in the bottom $2.5 \%$ and the top $2.5 \%$ of the distribution of the loan amount. The robustness checks, available upon request, suggest that the relationship between loan size and the probability of securitization is a very robust feature of our dataset. 


\section{Selection into Securitization and Causal Effects of Securitization: A Model}

One important question is whether lower quality loans are selected for securitization. In this section, we present a model of selection into securitization that allows for the possibility that securitized loans differ in ex ante quality from loans held on balance sheet. The purpose of the model is to distinguish between the causal effect of securitization on default and selection into securitization based on risk. In contrast to the residential market, commercial mortgages usually provide the lender with substantial prepayment protection such that the main risk to a commercial mortgage lender is default, not prepayment. ${ }^{11}$ Commercial loans are thus particularly suitable to isolate the differences in default between securitized and balance sheet loans. As such, the main difference in loan quality relates to its default risk.

The model posits that loan quality is persistent across time such that loans that are lower quality at origination default more. The model also incorporates any causal effect securitization may have on loan performance. While the securitization status of our mortgages is overwhelmingly determined at origination, unlike in the CLO market and the residential mortgage market, the potential for adverse selection nevertheless exists. One can imagine a situation in which borrowers turn to the CMBS market only after having been repeatedly rejected by balance sheet lenders because of poor soft information. If CMBS investors will not invest in acquiring such soft information,

\footnotetext{
${ }^{11}$ Such prepayment protection can take the form of a lockout period, a yield maintenance fee, defeasance, or a combination of the above. A lockout period is a contractual stipulation wherein the borrower cannot repay the loan within a specified period of time. A yield maintenance fee is a fixed fee the borrower must pay the lender upon prepayment that compensates the lender for a lower reinvestment rate; the fee is proportional to the lender's assumed reinvestment rate. Finally, a defeasance clause requires a prepaying borrower to provide the lender with a set of US Treasury STRIPS that replicate the cash flows of the loan; see Dierker, Quan, and Torous (2005) for a detailed discussion of defeasance clauses.
} 
the result will be that securitized loans are of lower quality than balance sheet loans with the same hard information characteristics. See Loutskina and Strahan (2011) for a discussion of the issue of soft information in loan performance. Furthermore, although the conduit lending and balance sheet lending desks are separate inside big banks, the balance sheet lending desk may direct a loan they are not interested in funding due to its risk to the conduit lending desk. In this section, we model this potential adverse selection using default data.

\subsection{The Model}

To make our notion of adverse selection more concrete, we introduce some structure to the securitization decision in equation (1). In particular, we assume that

$$
Y_{i, t}^{*}=x_{i, t-1} \beta+\gamma \varepsilon_{i, t}^{D I S T R E S S}+\varepsilon_{i, t}^{C M B S} .
$$

The components $\varepsilon_{i, t}^{D I S T R E S S}$ and $\varepsilon_{i, t}^{C M B S}$ are orthogonal to each other and, unlike $u_{i, t}$ in (1), which is only a regression residual, they have a structural interpretation. Namely, $\varepsilon_{i, t}^{\text {DISTRESS }}$ captures unobservables that affect the likelihood that a loan will be in distress and at risk of default. In other words, $\varepsilon_{i, t}^{D I S T R E S S}$ represents soft information that cannot be captured by quantitative variables and hard information that is observable to the loan originator but not to the econometrician (such as the borrower's financial situation). The parameter $\gamma$, which will be the focus of much of our discussion, measures the extent to which securitized loans differ in their distress risk from balance sheet loans.

Our model allows the distress risk of securitized loans to differ from balance sheet

loans through selection but not causality. The assumption that $\varepsilon_{i, t}^{D I S T R E S S}$ and $\varepsilon_{i, t}^{C M B S}$ 
are orthogonal to each other does not imply that there is no relationship between a loan's securitization status and its quality. The model allows for the possibility that a borrower or lender's private information about the loan might drive them towards either a balance sheet or a securitized loan. Such selection occurs via the parameter $\gamma$. Rather, the economic interpretation of the assumption that $\varepsilon_{i, t}^{D I S T R E S S}$ and $\varepsilon_{i, t}^{C M B S}$ are independent is that the securitization status should not have a causal effect on whether the loan becomes distressed. As we discuss below, we allow for the possibility that a loan's securitization status influences whether a loan transitions from distress to default.

Securitization should not have a causal effect on whether a loan experiences distress. The key reasons that lead to a loan becoming distressed are the inability of the borrower to make the loan payments due to liquidity constraints and whether the default option is in the money in the sense of the property being worth less than the balance outstanding on the loan (for a discussion of the default option, see Deng, Quigley, and Van Order (2000)). Whether a particular loan is securitized affects neither the borrower's cash flow nor the price of the property. It is, of course, possible that the availability of securitized financing may affect aggregate asset values. Indeed, Adelino, Schoar, and Severino (2012) show that homes that can easily be financed using a conforming loan have higher prices than homes that are difficult to finance in the conforming market. However, whether a property is actually financed using a securitized loan should not affect the individual property's value. Hence, the CMBS variable does not enter into expression (4). This identifying assumption is equivalent to stating that, if we randomly assign half of a set of loans to securitization and the other half to balance sheet lenders, we do not expect securitization to affect the percentage of loans in each subset that experiences distress.

To recover $\varepsilon_{i, t}^{D I S T R E S S}$, which is not directly observable from the data, we model the 
financial condition of the borrower. Suppose that $Z_{i, t+1}^{*}$ is the financial condition of the borrower which depends on observable characteristics $\tilde{x}_{i, t-1}$ and on the unobservable $\varepsilon_{i, t+1}^{D I S T R E S S}$. Hence, we write

$$
Z_{i, t+1}^{*}=\tilde{x}_{i, t-1} \eta+\varepsilon_{i, t+1}^{D I S T R E S S},
$$

and we assume that the process for the unobserved risk of the loan is

$$
\varepsilon_{i, t+1}^{D I S T R S S}=\varepsilon_{i, t}^{D I S T R E S S}+v_{i, t+1},
$$

where $v_{i, t+1}$ is an independently and identically distributed zero-mean random variable.

Equation (5) implies that the distress shock is unforecastable but that distress risk is persistent. We could assume that the process for $\varepsilon_{i, t+1}^{D I S T R E S S}$ follows a more general AR1 process but that would introduce another parameter to the analysis with no increase in economic intuition. All of the intuition for the model carries through, however, if $\varepsilon_{i, t+1}^{D I S T R E S S}$ follows an AR1 rather than a random walk. To illustrate how $\varepsilon_{i, t+1}^{\text {ISTRESS }}$ affects whether the loan is securitized, suppose that a loan has a high value of $\varepsilon_{i, t}^{D I S T R E S S}$. If $\gamma>0$, the likelihood of securitization will increase. Therefore, for $\gamma>0$, there is adverse selection into the CMBS market, i.e., the CMBS market has lower quality loans than the balance sheet market. If $\gamma<0$, loans in the CMBS market are less likely to default than balance sheet loans. Hence, $\gamma$ is the parameter that captures adverse selection that we want to estimate.

It is tempting to model default as an index function, i.e., $D_{i, t+1}=1$ if $Z_{i, t}^{*}>$ 0 and zero otherwise. If distress were directly observable, then we could specify $P\left(D_{i, t+1}=1\right)=P\left(Z_{i, t+1}^{*}>0\right)=F\left(\tilde{x}_{i, t-1} \eta\right)$, and under a functional form assump- 
tion on $F($.$) , we could estimate the parameters of this model with a probit or a logit.$ However, we do not observe distress. We observe when a loan is in default as defined in Section 2. Using conditioning, and the fact that a loan must be distressed in order to default, we can write

$$
\begin{aligned}
P\left(D_{i, t+1}=1\right) & =P\left(D_{i, t+1}=1 \mid \text { Distress }_{i, t+1}=1\right) * P\left(\text { Distress }_{i, t+1}=1\right) \\
& =p_{i, t+1} P\left(Z_{i, t+1}^{*}>0\right)
\end{aligned}
$$

The probability that a distressed loan actually defaults, $p_{i, t+1}$, has a natural interpretation. Its complement, $1-p_{i, t+1}=P(D=0 \mid$ Distress $=1)$, is the probability that the loan does not default given that it was in distress. This can happen for a variety of reasons. The cash flow of the borrower may improve following favorable changes in market, industry, or firm-specific conditions, or the value of the collateral can increase. In such cases, there is no difference in $p_{i, t+1}$ between CMBS and non-CMBS loans and we can let $p_{i, t+1}=p_{t}$.

However, securitization may influence whether a distressed loan experiences a default due to agency issues. In particular, securitization may make it more difficult to renegotiate distressed loans in such a way as to avoid a default. Several papers discuss the role of securitization in residential mortgage renegotiation. ${ }^{12}$ Although CMBS loans have special servicers that are designed to mitigate the sorts of agency problems that arise from dispersed ownership and interest, the presence of special servicers may not entirely eliminate agency problems in distressed loan renegotiation. Indeed, Gan and Mayer (2007) and Ambrose, Sanders, and Yavas (forthcoming) identify the potential for agency issues in renegotiating CMBS loans.

\footnotetext{
${ }^{12}$ See Cordell, Dynan, Lehnert, Liang, and Mauskopf (2009), Piskorski, Seru, and Vig (2010), Agarwal, Amromin, Ben-David, Chomsisengphet, and Evanoff (2011), Ghent (2011), and Adelino, Gerardi, and Willen (2013).
} 
To incorporate this channel into our model, we let $p_{i, t+1}$ be a function of whether a loan has been securitized or not, or $p_{i, t+1}=f\left(C M B S_{i, t} ; \alpha\right)$ and $\alpha$ is a parameter. We adopt the simple function

$$
p_{i, t+1}= \begin{cases}1 & C M B S_{i, t}=1 \\ \alpha & C M B S_{i, t}=0\end{cases}
$$

where we have normalized the probability that a loan defaults conditional on it being distressed to 1 for CMBS loans. ${ }^{13}$ Given this normalization, $\alpha<1$ implies that the probability that a CMBS loans transitions from a state of distress to a state of default is higher (and the renegotiation rate is lower) than that of a balance sheet loan. In our context, $\alpha$ is simply a nuisance parameter; we do not have enough data to reliably estimate $\alpha$. Hence, we estimate the model for a range of values of $\alpha$.

\subsection{Estimation Procedure}

Based on the structure of equations (3)-(7), we first estimate $P\left(D_{i, t+1}=1\right)$ for a given $\alpha$ using maximum likelihood. In our empirical implementation, we assume that $F\left(\tilde{x}_{i, t-1} \eta\right)=\Phi\left(\tilde{x}_{i, t-1} \eta\right)$. Second, we extract an estimate of $\varepsilon_{i, t}^{D I S T R E S S}$, denoted by $\hat{\varepsilon}_{i, t+1}^{D I S T R E S S}$, using generalized residuals (Chesher and Irish (1987) and Greene (2000), pp. 916-917). The estimate $\hat{\varepsilon}_{i, t+1}^{D I S T R E S S}$ is analogous to the usual regression residual, with the exception that here we are working with a probit rather than a linear model. Third, we estimate (3) assuming $F(\cdot)$ is the standard normal distribution and compute standard errors using a nonparametric bootstrap. Simply estimating a

\footnotetext{
${ }^{13}$ We verify that our results are robust to this normalization by also considering $p_{i, t}=p$ for CMBS loans and $p_{i, t}=\alpha p$ for balance sheets and estimating the model for various values of $p$. The results for $p=0.75$ and $p=0.5$ are available in an appendix. When $p$ is quite small, for example 0.25 , it becomes difficult to estimate the standard errors via the bootstrap procedure because the likelihood function is close to flat. Intuitively, the likelihood function loses its curvature because the information about a loan's default status contains little information about the loan's distress status.
} 
probit model with the given data and with $\hat{\varepsilon}_{i, t+1}^{D I S T R E S S}$ in place of $\varepsilon_{i, t}^{D I S T R E S S}$ would yield incorrect standard errors, because the uncertainty associated with estimating $\hat{\varepsilon}_{i, t+1}^{\text {DISTRESS }}$ is not taken into account; see Pagan (1984). In the interest of brevity, we present results for only $\alpha=0.8, \alpha=0.9$, and $\alpha=1.0$; the results for other values of $\alpha$ are available upon request. The appendix details the derivation and estimation of the generalized residuals.

\subsection{First Stage (Default) Results}

Table 5 presents our results from estimating equation (6) via maximum likelihood for three different values of $\alpha(\alpha=1.0, \alpha=0.9, \alpha=0.8)$ for both all originations (columns 1 - 3) and the subsample of loans originated by depository institutions (columns $4-6)$. The estimates in Table 4 assume that $F\left(\tilde{x}_{i, t-1} \eta\right)=\Phi\left(\tilde{x}_{i, t-1} \eta\right)$. When $\alpha=1.0$, the first stage of the estimation is thus identical to estimating a probit model. The results for $\alpha=1.0$ are in columns 1 and 4 .

Table 5 illustrates that higher loan amounts increase the likelihood of default. Loans originated by depository institutions default less frequently than other loans highlighting the potential for heterogeneity in what kinds of originators originate which sorts of loans. Furthermore, the coefficients on the log of the lender's assets in columns 4 through 6 indicate that larger lenders in general tend to originate higher quality loans. However, with a p-value of $11 \%$, the coefficient on the log of the lender's assets is not statistically significant at conventional levels.

Perhaps surprisingly, the loan-to-value ratio is not a statistically significant predictor of default, although the coefficient is positive. While LTV is consistently a strong predictor of default in the residential mortgage literature, consistent with intuition regarding the importance of the default option value, previous studies using 
commercial mortgage data have seen mixed results regarding the LTV. Titman and Tsyplakov (2010) find that higher LTV loans do default more frequently. However, An, Deng, and Gabriel (2011) find that an increase in the LTV actually lowers the risk of default. They attribute this finding to higher risk borrowers being unable to secure higher LTV loans. Ambrose and Sanders (2003) find no statistically significant relationship between the LTV and default.

The difference in the findings regarding the role of LTV in default between the residential mortgage market and the commercial mortgage market illustrates an important difference between the two markets. In the US residential mortgage market, borrowers do not often negotiate with lenders regarding the terms of their loans. Rather, because of high fixed costs of evaluating each residential borrower's unique circumstances, lenders offer programs that place limits on some combination of the FICO score, the LTV, and perhaps debt-to-income. Competition from borrowers thus takes the form of the number of programs available. In contrast, because of the large size of commercial mortgages, each commercial mortgage entails a careful evaluation

of the borrower. Only the most credit-worthy borrowers are likely to be able to access high LTV commercial mortgages.

Although Table 5 does not present the coefficients for the MSA fixed effects, loans from LA and Las Vegas default at much higher rates than loans from Boston or NYC.

\subsection{Second Stage (CMBS Selection) Results}

Columns (1) and (4) of Table 6 present the results from estimating equation (3) for $\alpha=1$ in our full sample and in the sample of depository originators only. In both specifications, the sign of $\gamma$ is positive but statistically insignificant. The coefficients on all the other variables are nearly identical to what we found in Table 3, which is 
not surprising given that $\hat{\varepsilon}_{i, t+1}^{D I S T R E S S}$ is orthogonal to $\tilde{x}_{i, t-1}$. The economic magnitudes of the effects of the independent variables are thus also very similar to those shown in Table 3. Including $\hat{\varepsilon}_{i, t+1}^{D I S T R E S S}$ also does not significantly increase the pseudo- $R^{2}$ relative to that in Table 3. The conclusion from Table 6 is that for $\alpha=1$, i.e., for the case of no difference in renegotiation between CMBS and balance sheet loans, the only evidence of adverse selection is in the sample of loans originated by depository institutions. Although $\hat{\gamma}$ is not statistically significant at conventional levels, the $p$ value is $11 \%$. The results for non-depository institutions are available in the appendix: The estimate of $\gamma$ is always negative and is never statistically significant, which is not in support of the adverse selection hypothesis.

The difficulty of identifying adverse selection is more apparent when $\alpha=0.9$ (columns (2) and (5)) or $\alpha=0.8$ (columns (3) and (6)). The estimate of $\gamma$ falls and becomes far from significant in both the full sample and the sample of loans originated by depository institutions. In the full sample, the sign of $\hat{\gamma}$ becomes negative when $\alpha=0.9$ or $\alpha=0.8$. Even if we had found strong evidence that CMBS loans default more when ignoring any causal effect securitization may have on loan performance (i.e., when $\alpha=1$ ), our model illustrates that it is difficult to conclude from such evidence that there is adverse selection without knowing the extent of agency problems that may affect loan performance.

Investors care not only about whether a loan defaults but about what they recover in the event of a default. It is possible that, although CMBS loans do not default more than balance sheet loans after controlling for observable characteristics, the loss given default is more severe for securitized loans. For the sample of defaulted loans that have been resolved, we thus compare the recovery rates of CMBS and balance sheet loans. The mean recovery rates on CMBS and balance sheet loans are $72 \%$ and $70 \%$; the univariate difference between the recovery rates is not statistically significant. 
Excluding loans with a recovery rate of $100 \%$, the mean recovery rates on CMBS and balance sheet loans are both $61 \%$. Excluding development loans, the mean recovery rates on CMBS and balance sheet loans are $68 \%$ and $71 \%$; the difference is statistically insignificant. We also run regressions of the recovery rate on the securitization status of the loan and controls such as the city the property is in, the year the loan was originated, the year the loan defaulted, and the length of time it took for the lender to resolve the default. In no specification do we find the coefficient on CMBS to be close to statistically significant.

In summary, there is little evidence of adverse selection from securitization in the market for commercial mortgages. Our finding that securitized loans do not appear to have lower unobserved quality is consistent with the findings of Benmelech, Dlugosz, and Ivashina (2012) in the CLO market. Agarwal, Chang, and Yavas (2012) find that securitized prime residential mortgages are in fact less likely to terminate through default than prime mortgages retained by the originator; they suggest that the reason securitized mortgages default less is because of the dominance of the GSEs in the prime market. Agarwal, Chang, and Yavas find no difference in the performance of securitized and portfolio mortgages in the subprime market. Ambrose, Lacour-Little, and Sanders (2005) and Bubb and Kaufman (2014) also find no evidence of adverse selection in the residential mortgage market. Jiang, Nelson, and Vytlacil (2013) find that securitized residential mortgages actually perform better than balance sheet loans.

In contrast, Keys, Mukherjee, Seru, and Vig (2010) and Krainer and Laderman (2014) present evidence that securitized residential loans are riskier. Downing, Jaffee, and Wallace (2009) find evidence of adverse selection in the Collateralized Mortgage Obligation (CMO) market. They find that the Freddie Mac participation certificates, mortgage backed securities themselves, that are re-securitized into CMOs carry 
greater prepayment risk. Within the universe of securitized commercial mortgages, An, Deng, and Gabriel (2011) also find that mortgages originated with the possibility of being held on a lender's balance sheet have different modeled prices than loans originated through conduits.

\subsection{Resolution of Default}

Although we cannot directly estimate $\alpha$ as we do not observe early stage renegotiation that may occur, we do observe how loans that are in serious default get resolved. Observing any differences in the resolution of loans across CMBS and balance sheets may demonstrate the presence of the sorts of agency issues that would cause $\alpha$ to be less than 1.

As of May 2012, many defaulted loans remained unresolved. Of the defaulted balance sheet loans, $55 \%$ had been resolved. Of the defaulted CMBS loans, only $31 \%$ had been resolved. Table 7 illustrates that the difference in the propensity of balance sheet and securitized loans to get resolved remains after controlling for the MSA, the year of origination, the loan amount, and the year the loan became distressed. The estimates indicate that CMBS loans are about 19\% less likely to be resolved than balance sheet loans. The effect is statistically significant at the $5 \%$ level. Although it is possible that CMBS servicers delay resolution of defaulted loans to find a buyer that values the asset more highly, and are thus more efficient than balance sheet lenders in resolving defaults, the recovery rates are not higher among balance sheet loans. A likely explanation of this finding is that CMBS loans experience lower rates of renegotiation (something we cannot observe directly) which leads to lower resolution rates of those loans. In other words, the differences in the pace of resolution suggest that CMBS special servicers may not be properly incentivized. 


\section{Conclusions}

In this paper, we presented evidence that risk-sharing is one key benefit of diversification using data from commercial mortgages. By far the most important determinant of whether a loan is securitized is the size of the loan. Securitization of large loans allows lenders to manage risk by diversifying the idiosyncratic risk of a large potential default. The importance of loan size thus underscores the benefits of securitization in financial markets. We also found evidence that securitization is less prevalent among loans that require substantial monitoring on the part of the lender. A troubling finding is that special servicers are not as effective as balance sheet lenders in resolving distressed loans. In the absence of government guarantees, such as those that the GSEs provide in the residential mortgage market, lenders appear to turn to securitization only when the benefits, such as diversification, are large enough to outweigh the agency costs associated with securitization. Although diversification is a benefit to lenders that enables greater loan supply, and is thus often socially beneficial, certain other benefits to lenders, such as regulatory arbitrage (see Stanton and Wallace (2012) and Acharya, Schnabl, and Suarez (2013)), may be socially harmful.

We also documented the collapse of the CMBS market since 2008. In contrast, the balance sheet commercial mortgage market has recovered somewhat since 2008 and never came to a standstill the way the CMBS market did. Our finding that, overall, CMBS and balance sheet loans experienced similar defaults during the recent financial crisis indicates that there may be reasons other than poorer loan performance for the collapse of securitization in the aftermath of the financial crisis. Interestingly, the pattern of commercial mortgage securitization that we observe bears a sharp resemblance to the pattern that Goetzmann and Newman (2010) document in the 1920s and 1930s. They find that many skyscrapers built during that period were 
financed using large CMBS loans. The loan sizes at the time were larger than what balance sheet lenders were accustomed to making for a single property. In the 1930s, the CMBS market collapsed completely and did not return on any substantial scale until the 1990s. While our results provide insights into the loan-level differences between securitized and balance sheet borrowing, we hope future research can explain differences over time in securitization rates. 
Table 1: Summary Statistics

\begin{tabular}{|c|c|c|c|c|c|c|}
\hline \multirow[t]{2}{*}{ Characteristic } & Mean & SD & Skew & Min & $\operatorname{Max}$ & No. Obs. \\
\hline & \multicolumn{6}{|c|}{ Entire Sample: Jan 2005 - Apr 2012 Originations } \\
\hline CMBS & 0.187 & 0.390 & 1.6 & 0 & 1 & 1962 \\
\hline Loan Amount $(\$ \mathrm{M})$ & 32.2 & 88.4 & 8.8 & 0.2 & 1,900 & 1962 \\
\hline Loan-to-Value (LTV) & 0.75 & 0.46 & 8.6 & 0.03 & 9.73 & 1962 \\
\hline Origination Year & 2007.24 & 2.05 & 0.8 & 2005 & 2012 & 1962 \\
\hline Property Price $(\$ M)$ & 49.4 & 153.0 & 8.7 & 1.6 & 2,950 & 1962 \\
\hline Price / Square Foot $(\$)$ & 338.5 & 337.5 & 5.2 & 11 & 4,933 & 1962 \\
\hline Year Built & 1962.4 & 33.8 & -1.0 & 1732 & 2011 & 1962 \\
\hline Square Feet $\left(\times 10^{3}\right)$ & 131.50 & 245.78 & 5.0 & 0.90 & $2,961.07$ & 1962 \\
\hline Floors & 6.44 & 8.48 & 3.4 & 1 & 77 & 1830 \\
\hline Multiple Building & 0.065 & 0.256 & 3.5 & 0 & 1 & 1962 \\
\hline Central Business District (CBD) & 0.356 & 0.479 & 0.6 & 0 & 1 & 1962 \\
\hline NYC Metro & 0.429 & 0.495 & 0.3 & 0 & 1 & 1962 \\
\hline LA Metro & 0.388 & 0.488 & 0.5 & 0 & 1 & 1962 \\
\hline Boston Metro & 0.138 & 0.345 & 2.1 & 0 & 1 & 1962 \\
\hline Las Vegas Metro & 0.045 & 0.207 & 4.4 & 0 & 1 & 1962 \\
\hline \multicolumn{7}{|l|}{ Borrower-Specific: } \\
\hline Developer/Owner & 0.647 & 0.478 & -0.6 & 0 & 1 & 1962 \\
\hline Equity Fund & 0.085 & 0.279 & 3.0 & 0 & 1 & 1962 \\
\hline Corporate & 0.062 & 0.241 & 3.6 & 0 & 1 & 1962 \\
\hline REIT & 0.043 & 0.204 & 4.5 & 0 & 1 & 1962 \\
\hline Unknown & 0.080 & 0.271 & 3.1 & 0 & 1 & 1962 \\
\hline \multicolumn{7}{|l|}{ Originator-Specific: } \\
\hline \multirow[t]{2}{*}{ Depository US Inst. } & 0.543 & 0.498 & -0.2 & 0 & 1 & 1962 \\
\hline & \multicolumn{6}{|c|}{ Sub-Sample: Jan 2005- Dec 2007 Originations } \\
\hline CMBS & 0.271 & 0.445 & 1.0 & 0 & 1 & 1306 \\
\hline Loan Amount $(\$ \mathrm{M})$ & 36.2 & 98.9 & 8.7 & 0.2 & 1,900 & 1306 \\
\hline Loan-to-Value (LTV) & 0.76 & 0.45 & 8.6 & 0.03 & 9.73 & 1306 \\
\hline Origination Year & 2006.00 & 0.82 & 0.0 & 2005 & 2007 & 1306 \\
\hline Property Price $(\$ M)$ & 53.8 & 165.5 & 8.7 & 1.6 & 2,950 & 1306 \\
\hline Price / Square Foot $(\$)$ & 335.8 & 293.5 & 3.6 & 43 & 3,449 & 1306 \\
\hline Year Built & 1962.9 & 33.3 & -1.1 & 1732 & 2008 & 1306 \\
\hline Square Feet $\left(\times 10^{3}\right)$ & 138.73 & 248.43 & 4.7 & 3.00 & 2,840 & 1306 \\
\hline Floors & 6.47 & 8.30 & 3.3 & 1 & 70 & 1210 \\
\hline Multiple Building & 0.065 & 0.248 & 3.5 & 0 & 1 & 1306 \\
\hline Central Business District (CBD) & 0.352 & 0.478 & 0.6 & 0 & 1 & 1306 \\
\hline NYC Metro & 0.423 & 0.494 & 0.3 & 0 & 1 & 1306 \\
\hline LA Metro & 0.385 & 0.487 & 0.5 & 0 & 1 & 1306 \\
\hline Boston Metro & 0.136 & 0.342 & 2.1 & 0 & 1 & 1306 \\
\hline Las Vegas Metro & 0.056 & 0.230 & 3.9 & 0 & 1 & 1306 \\
\hline \multicolumn{7}{|l|}{ Borrower-Specific: } \\
\hline Developer/Owner & 0.650 & 0.477 & -0.6 & 0 & 1 & 1306 \\
\hline Equity Fund & 0.093 & 0.290 & 2.8 & 0 & 1 & 1306 \\
\hline Corporate & 0.043 & 0.203 & 4.5 & 0 & 1 & 1306 \\
\hline REIT & 0.046 & 0.209 & 4.4 & 0 & 1 & 1306 \\
\hline Unknown & 0.090 & 0.287 & 2.9 & 0 & 1 & 1306 \\
\hline \multicolumn{7}{|l|}{ Originator-Specific: } \\
\hline Depository US Inst. & 0.530 & 0.500 & -0.1 & 0 & 1 & 1306 \\
\hline
\end{tabular}

Notes: The table contains summary statistics of the data consisting of all purchase office commercial mortgages in Boston, Las Vegas, Los Angeles, and New York from January 2005 to April 2012. The dichotomous variable "CMBS" denotes whether a loan is securitized. The other characteristics of the loan are defined in section 2 . 
Table 2: Balance Sheet and Securitized Loans

\begin{tabular}{lccccccc}
\hline \hline & \multicolumn{3}{c}{ Balance Sheet } & \multicolumn{3}{c}{ Securitized (CMBS) } & Difference \\
Characteristic & Mean & SD & Skew & Mean & SD & Skew & in Means \\
\hline Loan Amount $(\$ M)$ & 24.8 & 75.8 & 12.2 & 64.4 & 124.9 & 4.3 & $-39.6^{* * *}$ \\
Development $(\mathrm{LTV} \geq 1)$ & 0.129 & 0.335 & 2.2 & 0.030 & 0.171 & 5.5 & $0.099^{* * *}$ \\
LTV & 0.756 & 0.51 & 8.1 & 0.722 & 0.17 & 0.7 & 0.035 \\
Origination Year & 2007.50 & 2.12 & 0.6 & 2006.14 & 1.18 & 2.0 & $1.35^{* * *}$ \\
Property Price $(\$ M)$ & 37.3 & 128.6 & 11.8 & 102.0 & 223.6 & 4.6 & $-64.7^{* * *}$ \\
Price / Square Foot $(\$)$ & 340.9 & 359.6 & 5.1 & 328.3 & 216.9 & 1.9 & 12.6 \\
Year Built & 1960.62 & 34.08 & -0.8 & 1969.98 & 31.33 & -2.1 & $-9.36^{* * *}$ \\
Square Feet & 105,910 & 210,950 & 5.9 & 242,729 & 338,511 & 3.3 & $-136,818^{* * *}$ \\
Floors & 5.89 & 7.84 & 3.9 & 8.94 & 10.59 & 2.3 & $-3.05^{* * *}$ \\
Multiple Building & 0.051 & 0.221 & 4.1 & 0.123 & 0.328 & 2.3 & $-0.071^{* * *}$ \\
CBD & 0.367 & 0.482 & 0.6 & 0.305 & 0.461 & 0.9 & $0.062^{* *}$ \\
NYC Metro & 0.421 & 0.494 & 0.3 & 0.463 & 0.499 & 0.1 & -0.042 \\
LA Metro & 0.401 & 0.490 & 0.4 & 0.332 & 0.472 & 0.7 & $0.069^{* *}$ \\
Boston Metro & 0.139 & 0.346 & 2.1 & 0.134 & 0.341 & 2.2 & 0.005 \\
Las Vegas Metro & 0.039 & 0.193 & 4.8 & 0.071 & 0.257 & 3.3 & $-0.032^{* * *}$ \\
Borrower-Specific: & & & & & & & \\
Developer/Owner & 0.656 & 0.475 & -0.7 & 0.608 & 0.489 & -0.4 & $0.049^{*}$ \\
Equity Fund & 0.071 & 0.258 & 3.3 & 0.144 & 0.352 & 2.0 & $-0.073^{* * *}$ \\
Corporate & 0.071 & 0.258 & 3.3 & 0.019 & 0.137 & 7.0 & $0.052^{* * *}$ \\
REIT & 0.030 & 0.171 & 5.5 & 0.101 & 0.301 & 2.7 & $-0.071^{* * *}$ \\
Unknown & 0.088 & 0.284 & 2.9 & 0.044 & 0.204 & 4.5 & $0.045^{* * *}$ \\
Originator-Specific: & & & & & & & \\
Depository US Inst. & 0.547 & 0.497 & -0.2 & 0.529 & 0.500 & -0.1 & 0.018 \\
\hline \hline Note Sim & & & & &
\end{tabular}

Notes: Summary statistics of the January 2005 to April 2012 sample, which is split into balance sheet and securitized (CMBS) loans. The exact definition of the variables can be found in section 2 . The difference in the means of loan characteristics is reported in the last column. ${ }^{* * *}$ and ${ }^{* *}$ denote that the difference between balance sheet and CMBS loans is significant at the $1 \%$ and $5 \%$ level. 
Table 3: Probit Estimation of Loan Securitization

\begin{tabular}{|c|c|c|c|c|c|c|}
\hline & \multirow[t]{2}{*}{$(1)$} & $(2)$ & \multirow[t]{2}{*}{$\overline{(3)}$} & $(4)$ & $(5)$ & \multirow{2}{*}{$\begin{array}{c}(6) \\
\text { Largest } 10\end{array}$} \\
\hline & & Full Sample & & \multicolumn{2}{|c|}{ Depository } & \\
\hline Constant & $\begin{array}{c}-2.78^{* * *} \\
(0.23)\end{array}$ & $\begin{array}{c}-2.94^{* * *} \\
(0.24)\end{array}$ & $\begin{array}{c}-3.05^{* * *} \\
(0.29)\end{array}$ & $\begin{array}{c}-5.19^{* * *} \\
(0.54)\end{array}$ & $\begin{array}{c}-5.08^{* * *} \\
(0.49)\end{array}$ & $\begin{array}{c}-0.86 \\
0.53\end{array}$ \\
\hline Log Loan Amount & $\begin{array}{c}0.48^{* * *} \\
(0.04) \\
8.7 \%\end{array}$ & $\begin{array}{c}0.49^{* * *} \\
(0.04) \\
8.9 \%\end{array}$ & Deciles & $\begin{array}{c}0.57^{* * *} \\
(0.06) \\
9.6 \%\end{array}$ & & $\begin{array}{c}0.41^{* * *} \\
0.06 \\
8.5 \%\end{array}$ \\
\hline Log Lender Assets & & & & $\begin{array}{c}0.15^{* * *} \\
0.03 \\
2.5 \%\end{array}$ & $\begin{array}{c}0.21^{* * *} \\
0.03 \\
4.3 \%\end{array}$ & \\
\hline Loan Amt./ Lender Assets & & & & & $\begin{array}{c}12.50^{* * *} \\
4.07 \\
251 \%\end{array}$ & \\
\hline Development $(\mathrm{LTV} \geq 1)$ & $\begin{array}{c}-1.19 * * * \\
(0.21) \\
-21 \%\end{array}$ & $\begin{array}{c}-1.18^{* * *} \\
(0.22) \\
-22 \%\end{array}$ & $\begin{array}{c}-1.15^{* * *} \\
(0.21) \\
-20 \%\end{array}$ & $\begin{array}{c}-1.62 \text { *** } \\
(0.38) \\
-27 \%\end{array}$ & $\begin{array}{c}-1.79 * * * \\
(0.37) \\
-36 \%\end{array}$ & $\begin{array}{c}-1.84^{* * *} \\
(0.41) \\
-38 \%\end{array}$ \\
\hline LTV & $\begin{array}{c}-0.21 \\
(0.15) \\
-4 \%\end{array}$ & $\begin{array}{c}-0.21 \\
(0.15) \\
-4 \%\end{array}$ & $\begin{array}{c}-0.37^{* *} \\
(0.18) \\
-6 \%\end{array}$ & $\begin{array}{c}0.10 \\
(0.27) \\
2 \%\end{array}$ & $\begin{array}{c}0.63^{* * *} \\
(0.18) \\
13 \%\end{array}$ & $\begin{array}{c}0.02 \\
(0.32) \\
3 \%\end{array}$ \\
\hline Price per Square Foot & $\begin{array}{c}-0.39 * * \\
(0.18)\end{array}$ & $\begin{array}{c}-0.41^{* *} \\
(0.18)\end{array}$ & $\begin{array}{l}-0.16 \\
(0.14)\end{array}$ & $\begin{array}{l}-0.10 \\
(0.25)\end{array}$ & $\begin{array}{c}0.13 \\
(0.19)\end{array}$ & $\begin{array}{l}-0.07 \\
(0.29)\end{array}$ \\
\hline CBD & $\begin{array}{c}-0.65^{* * *} \\
(0.15) \\
-12 \%\end{array}$ & $\begin{array}{c}-0.66^{* * *} \\
(0.15) \\
-12 \%\end{array}$ & $\begin{array}{c}-0.57^{* * *} \\
(0.15) \\
-10 \%\end{array}$ & $\begin{array}{c}-0.75^{* * *} \\
(0.24) \\
-13 \%\end{array}$ & $\begin{array}{c}-0.01 \\
(0.19) \\
-2 \%\end{array}$ & $\begin{array}{c}-0.53^{* *} \\
(0.24) \\
-11 \%\end{array}$ \\
\hline Multi-building & $\begin{array}{c}0.26 \\
(0.16) \\
4.7 \%\end{array}$ & $\begin{array}{c}0.25 \\
(0.16) \\
4.5 \%\end{array}$ & $\begin{array}{c}0.27^{*} \\
(0.15) \\
4.8 \%\end{array}$ & $\begin{array}{c}0.64^{* *} \\
(0.30) \\
10.7 \%\end{array}$ & $\begin{array}{c}1.03^{* * *} \\
(0.25) \\
20.1 \%\end{array}$ & $\begin{array}{c}0.25 \\
(0.28) \\
5.1 \%\end{array}$ \\
\hline Depository US Inst. & & $\begin{array}{c}0.21^{* *} \\
(0.08) \\
3.8 \%\end{array}$ & & & & \\
\hline Orig. Yr. FEs $(2005,2006$, and 2007) & Yes & Yes & Yes & Yes & Yes & Yes \\
\hline MSA FEs & Yes & Yes & Yes & Yes & Yes & Yes \\
\hline Prop. Age FEs $(<1960,60-80,80-00)$ & Yes & Yes & Yes & Yes & Yes & Yes \\
\hline Borrower Type FEs & Yes & Yes & Yes & Yes & Yes & Yes \\
\hline Originator FEs & No & No & No & No & No & Yes \\
\hline Number of Obs. & 1962 & 1962 & 1962 & 825 & 825 & 514 \\
\hline Pseudo- $R^{2}$ & $32 \%$ & $33 \%$ & $35 \%$ & $41 \%$ & $30 \%$ & $44 \%$ \\
\hline
\end{tabular}

Notes: The table contains estimates of a probit where the dependent variable takes a value of 1 if the loan is securitized and 0 otherwise (equation (2) in the text). The estimates are obtained from a pooled dataset of all loans in our January 2005 to April 2012 sample. In all six specifications, the first entry for each variable is the coefficient, the second entry (in parentheses) is the robust standard error, and the third entry is the effect of a 1 unit change in the independent variable (the other characteristics are held fixed at their actual values). In all specifications, we include year and MSA fixed effects. In the specification presented in column 3, the loan amount is included in deciles rather than as a continuous variable; the coefficients and significance on each of the size deciles are reported in Figure 3. The specifications in columns 4 and 5 include only loans originated by depository US institutions and for which we have asset information on the lender in the quarter the loan is originated. The specification in column 69 includes only loans originated by the largest 10 originators that originate both balance sheet and CMBS loans in our sample. ${ }^{* * *}$ and ${ }^{* *}$ denote significance at the $1 \%$ and $5 \%$ levels. Coefficients and standard errors shown on Price per Square Foot are $\times 10^{3}$. 
Table 4: Estimation of Loan Securitization with Controls for Borrower Risk

\begin{tabular}{lcccc}
\hline \hline & $(1)$ & $(2)$ & $(3)$ & $(4)$ \\
\hline Constant & $-14.7^{* * *}$ & $-15.2^{* * *}$ & $-15.4^{* * *}$ & $-16.3^{* * *}$ \\
& $(0.93)$ & $(1.06)$ & $(1.07)$ & $(1.16)$ \\
Log Loan Amount & $0.96^{* * *}$ & $0.86^{* * *}$ & $0.85^{* * *}$ & $0.98^{* * *}$ \\
& $(0.17)$ & $(0.18)$ & $(0.19)$ & $(0.22)$ \\
Development (LTV $\geq 1)$ & -0.24 & -0.27 & -0.064 & 0.36 \\
& $(0.54)$ & $(0.54)$ & $(0.55)$ & $(0.56)$ \\
LTV & -0.68 & -0.14 & -0.30 & -0.64 \\
& $(0.45)$ & $(0.56)$ & $(0.56)$ & $(0.56)$ \\
Price per Square Foot & 0.42 & $1.20^{*}$ & 0.91 & 0.97 \\
& $(0.58)$ & $(0.65)$ & $(0.66)$ & $(0.69)$ \\
CBD & -0.68 & -0.75 & -0.63 & $-1.11^{*}$ \\
& $(0.46)$ & $(0.48)$ & $(0.48)$ & $(0.61)$ \\
Multi-building & 0.54 & 0.61 & 0.57 & 0.60 \\
& $(0.48)$ & $(0.50)$ & $(0.48)$ & $(0.53)$ \\
\hline Orig. Yr. FEs $(2005,2006,2007)$ & Yes & Yes & Yes & Yes \\
MSA FEs (Boston, NYC, LA/Las Vegas) & Yes & Yes & Yes & Yes \\
Prop. Age FEs (<1960, 60-80, 80-00) & Yes & Yes & Yes & Yes \\
Borrower FEs & Yes & Yes & Yes & Yes \\
Minimum Loans per Borrower & 4 & 5 & 6 & 7 \\
Number of Obs. & 233 & 189 & 174 & 138 \\
Pseudo- $R^{2}$ & $48 \%$ & $47 \%$ & $46 \%$ & $48 \%$ \\
\hline \hline
\end{tabular}

Notes: The table contains estimates of a probit where the dependent variable takes a value of 1 if the loan is securitized and 0 otherwise (equation (2) in the text). The estimates are obtained from a pooled dataset of all loans in our January 2005 to April 2012 sample. In all specifications, the first entry for each variable is the coefficient and the second entry (in parentheses) is the robust standard error. In all specifications, we include year and MSA fixed effects. Given the small number of observations, we combine LA and Las Vegas into a single geographic fixed effect in this table. ${ }^{* * *}$ and ${ }^{* *}$ denote significance at the $1 \%$ and $5 \%$ levels. Coefficients and standard errors shown on Price per Square Foot are $\times 10^{3}$. 
Table 5: Maximum Likelihood Estimation of Default

\begin{tabular}{|c|c|c|c|c|c|c|}
\hline & (1) & $(2)$ & (3) & (4) & (5) & (6) \\
\hline & \multicolumn{3}{|c|}{$\begin{array}{l}\text { Full Sample } \\
\quad \alpha=0.9 \quad \alpha=0.8\end{array}$} & \multicolumn{3}{|c|}{ Depository } \\
\hline & $\alpha=1$ & $\alpha=0.9$ & $\alpha=0.8$ & $\alpha=1$ & $\alpha=0.9$ & $\alpha=0.8$ \\
\hline Constant & $\begin{array}{c}-2.36^{* * *} \\
(0.21)\end{array}$ & $\begin{array}{c}-2.33^{* * *} \\
(0.22)\end{array}$ & $\begin{array}{c}-2.29 * * * \\
(0.23)\end{array}$ & $\begin{array}{c}-1.89^{* * *} \\
(0.53)\end{array}$ & $\begin{array}{c}-1.87^{* * *} \\
(0.59)\end{array}$ & $\begin{array}{c}-1.84^{* * *} \\
(0.62)\end{array}$ \\
\hline Log Loan Amount & $\begin{array}{c}0.17^{* * *} * \\
(0.04)\end{array}$ & $\begin{array}{c}0.16^{* * *} \\
(0.04)\end{array}$ & $\begin{array}{c}0.16^{* * *} \\
(0.04)\end{array}$ & $\begin{array}{c}0.15^{* *} \\
(0.07)\end{array}$ & $\begin{array}{c}0.15^{* *} \\
(0.07)\end{array}$ & $\begin{array}{l}0.14^{*} \\
(0.08)\end{array}$ \\
\hline Log Lender Assets & & & & $\begin{array}{l}-0.05 \\
(0.03)\end{array}$ & $\begin{array}{l}-0.05 \\
(0.03)\end{array}$ & $\begin{array}{l}-0.05 \\
(0.03)\end{array}$ \\
\hline Development (LTV $\geq 1)$ & $\begin{array}{c}0.08 \\
(0.18)\end{array}$ & $\begin{array}{c}0.10 \\
(0.18)\end{array}$ & $\begin{array}{c}0.12 \\
(0.19)\end{array}$ & $\begin{array}{l}-0.13 \\
(0.37)\end{array}$ & $\begin{array}{l}-0.15 \\
(0.41)\end{array}$ & $\begin{array}{l}-0.16 \\
(0.50)\end{array}$ \\
\hline LTV & $\begin{array}{c}0.14 \\
(0.11)\end{array}$ & $\begin{array}{c}0.16 \\
(0.13)\end{array}$ & $\begin{array}{c}0.17 \\
(0.14)\end{array}$ & $\begin{array}{c}0.34 \\
(0.30)\end{array}$ & $\begin{array}{c}0.41 \\
(0.40)\end{array}$ & $\begin{array}{c}0.47 \\
(0.45)\end{array}$ \\
\hline Price per Square Foot & $\begin{array}{l}-0.06 \\
(0.18)\end{array}$ & $\begin{array}{l}-0.06 \\
(0.18)\end{array}$ & $\begin{array}{l}-0.05 \\
(0.19)\end{array}$ & $\begin{array}{l}-0.37 \\
(0.44)\end{array}$ & $\begin{array}{l}-0.37 \\
(0.45)\end{array}$ & $\begin{array}{l}-0.39 \\
(0.47)\end{array}$ \\
\hline CBD & $\begin{array}{c}0.01 \\
(0.16)\end{array}$ & $\begin{array}{c}0.02 \\
(0.17)\end{array}$ & $\begin{array}{c}0.03 \\
(0.17)\end{array}$ & $\begin{array}{c}0.42 \\
(0.27)\end{array}$ & $\begin{array}{c}0.43 \\
(0.28)\end{array}$ & $\begin{array}{c}0.46 \\
(0.28)\end{array}$ \\
\hline Multi-building & $\begin{array}{l}-0.16 \\
(0.21)\end{array}$ & $\begin{array}{l}-0.17 \\
(0.21)\end{array}$ & $\begin{array}{l}-0.18 \\
(0.22)\end{array}$ & $\begin{array}{l}-0.53 \\
(0.99)\end{array}$ & $\begin{array}{l}-0.56 \\
(1.00)\end{array}$ & $\begin{array}{l}-0.58 \\
(1.00)\end{array}$ \\
\hline Depository US Inst. & $\begin{array}{l}-0.16^{*} \\
(0.09)\end{array}$ & $\begin{array}{l}-0.17^{*} \\
(0.09)\end{array}$ & $\begin{array}{l}-0.18^{*} \\
(0.09)\end{array}$ & & & \\
\hline Orig. Yr. FEs $(2005,2006$, and 2007) & Yes & Yes & Yes & Yes & Yes & Yes \\
\hline MSA FEs & Yes & Yes & Yes & Yes & Yes & Yes \\
\hline Prop. Age FEs $(<1960,60-80,80-00)$ & Yes & Yes & Yes & Yes & Yes & Yes \\
\hline Borrower Type FEs & Yes & Yes & Yes & Yes & Yes & Yes \\
\hline Number of Obs. & 1962 & 1962 & 1962 & 825 & 825 & 825 \\
\hline
\end{tabular}

Notes: The table contains maximum likelihood estimates of default where the dependent variable takes a value of 1 if the loan is securitized and 0 otherwise (equation (4) in the text). The independent variables $x_{i, t-1}$ are the same as in Table 3.The assumption that $\alpha=1$ corresponds to no difference in the likelihood of distressed CMBS loans entering into default relative to balance sheet loans. Values of $\alpha<1$ imply that distressed CMBS loans are more likely to default than distressed balance sheet loans. The estimates are obtained from a pooled dataset of all loans in our January 2005 to April 2012 sample. In all specifications, the first entry for each variable is the coefficient and the second entry (in parentheses) is the standard error. ${ }^{* * *},{ }^{* *}$, and ${ }^{*}$ denote significance at the $1 \%, 5 \%$, and $10 \%$ levels. Coefficients and standard errors shown on Price per Square Foot are $\times 10^{3}$. 
Table 6: Probit Estimation of Loan Securitization from Structural Model

\begin{tabular}{|c|c|c|c|c|c|c|}
\hline & $\begin{array}{c}(1) \\
\alpha=1\end{array}$ & $\begin{array}{c}(2) \\
\text { Full Sample }\end{array}$ & $(3)$ & (4) & $\begin{array}{c}(5) \\
\text { Depository }\end{array}$ & (6) \\
\hline Constant & $\begin{array}{c}-3.00^{* * *} \\
(0.25)\end{array}$ & $\begin{array}{c}-3.01^{* * *} \\
(0.25)\end{array}$ & $\begin{array}{c}-3.01^{* * *} \\
(0.25)\end{array}$ & $\begin{array}{c}-5.71^{* * *} \\
(1.17)\end{array}$ & $\begin{array}{c}-5.71^{* * *} \\
(1.17)\end{array}$ & $\begin{array}{c}-5.71^{* * *} \\
(1.17)\end{array}$ \\
\hline Log Loan Amount & $\begin{array}{c}0.50^{* * *} \\
(0.04)\end{array}$ & $\begin{array}{c}0.50^{* * *} \\
(0.04)\end{array}$ & $\begin{array}{c}0.50^{* * *} \\
(0.04)\end{array}$ & $\begin{array}{c}0.61^{* * *} \\
(0.07)\end{array}$ & $\begin{array}{c}0.60 * * * \\
(0.07)\end{array}$ & $\begin{array}{c}0.60^{* * *} \\
(0.07)\end{array}$ \\
\hline Log Lender Assets & & & & $\begin{array}{c}0.15^{* * * *} \\
(0.03)\end{array}$ & $\begin{array}{c}0.15^{* * *} \\
(0.03)\end{array}$ & $\begin{array}{c}0.15^{* * *} \\
(0.03)\end{array}$ \\
\hline Development $(\mathrm{LTV} \geq 1)$ & $\begin{array}{c}-1.22^{* * *} \\
(0.25)\end{array}$ & $\begin{array}{c}-1.23^{* * *} \\
(0.25)\end{array}$ & $\begin{array}{c}-1.23^{* * *} \\
(0.25)\end{array}$ & $\begin{array}{c}-1.73^{* * *} \\
(0.50)\end{array}$ & $\begin{array}{c}-1.73^{* * *} \\
(0.50)\end{array}$ & $\begin{array}{c}-1.74^{* * *} \\
(0.50)\end{array}$ \\
\hline LTV & $\begin{array}{l}-0.23 \\
(0.15)\end{array}$ & $\begin{array}{l}-0.23 \\
(0.15)\end{array}$ & $\begin{array}{l}-0.22 \\
(0.15)\end{array}$ & $\begin{array}{c}0.10 \\
(0.31)\end{array}$ & $\begin{array}{c}0.11 \\
(0.31)\end{array}$ & $\begin{array}{c}0.11 \\
(0.31)\end{array}$ \\
\hline Price per Square Foot & $\begin{array}{c}-0.42^{* *} \\
(0.19)\end{array}$ & $\begin{array}{c}-0.43^{* *} \\
(0.19)\end{array}$ & $\begin{array}{c}-0.43^{* *} \\
(0.19)\end{array}$ & $\begin{array}{l}-0.09 \\
(0.29)\end{array}$ & $\begin{array}{l}-0.09 \\
(0.29)\end{array}$ & $\begin{array}{l}-0.10 \\
(0.29)\end{array}$ \\
\hline $\mathrm{CBD}$ & $\begin{array}{c}-0.67 * * * \\
(0.16)\end{array}$ & $\begin{array}{c}-0.67^{* * *} \\
(0.16)\end{array}$ & $\begin{array}{c}-0.67^{* * *} \\
(0.16)\end{array}$ & $\begin{array}{c}-0.78^{* * *} \\
(0.26)\end{array}$ & $\begin{array}{c}-0.77^{* * *} \\
(0.26)\end{array}$ & $\begin{array}{c}-0.77^{* * * *} \\
(0.26)\end{array}$ \\
\hline Multi-building & $\begin{array}{c}0.25 \\
(0.16)\end{array}$ & $\begin{array}{c}0.25 \\
(0.16)\end{array}$ & $\begin{array}{c}0.25 \\
(0.16)\end{array}$ & $\begin{array}{c}0.67^{* *} \\
(0.33)\end{array}$ & $\begin{array}{c}0.67^{* *} \\
(0.33)\end{array}$ & $\begin{array}{c}0.67^{* *} \\
(0.33)\end{array}$ \\
\hline Depository US Inst. & $\begin{array}{c}0.22^{* * *} \\
(0.08)\end{array}$ & $\begin{array}{c}0.22^{* * *} \\
(0.08)\end{array}$ & $\begin{array}{c}0.22^{* * *} \\
(0.08)\end{array}$ & & & \\
\hline$\hat{\varepsilon}_{i, t}^{D I S T R E S S}$ & $\begin{array}{c}0.0368 \\
(0.0706)\end{array}$ & $\begin{array}{l}-0.0017 \\
(0.0735)\end{array}$ & $\begin{array}{l}-0.0483 \\
(0.0768)\end{array}$ & $\begin{array}{c}0.1933 \\
(0.1195) \\
\end{array}$ & $\begin{array}{c}0.1619 \\
(0.1233) \\
\end{array}$ & $\begin{array}{c}0.1239 \\
(0.1277)\end{array}$ \\
\hline Orig. Yr. FEs $(2005,2006$, and 2007$)$ & Yes & Yes & Yes & Yes & Yes & Yes \\
\hline MSA FEs & Yes & Yes & Yes & Yes & Yes & Yes \\
\hline Prop. Age FEs $(<1960,60-80,80-00)$ & Yes & Yes & Yes & Yes & Yes & Yes \\
\hline Borrower Type FEs & Yes & Yes & Yes & Yes & Yes & Yes \\
\hline Number of Obs. & 1962 & 1962 & 1962 & 825 & 825 & 825 \\
\hline Pseudo- $R^{2}$ & $34 \%$ & $34 \%$ & $34 \%$ & $44 \%$ & $44 \%$ & $44 \%$ \\
\hline
\end{tabular}

Notes: The table contains estimates of a probit where the dependent variable takes a value of 1 if the loan is securitized and 0 otherwise (equation (3) in the text). The independent variables $x_{i, t-1}$ are the same as in Table 3 . We identify the distress variable $\varepsilon_{i, t}^{D I S T R E S S}$ using default rates of the loans (see section 4) under the assumptions about the value of $\alpha$ stated. The assumption that $\alpha=1$ corresponds to no difference in the likelihood of distressed CMBS loans entering into default relative to balance sheet loans. Values of $\alpha<1$ imply that distressed CMBS loans are more likely to default than distressed balance sheet loans. The estimates are obtained from a pooled dataset of all loans in our January 2005 to April 2012 sample. In all specifications, the first entry for each variable is the coefficient and the second entry (in parentheses) is the robust standard error. Standard errors are estimated using nonparametric bootstrap with 500 replications to take into account the fact that $\varepsilon_{i, t}^{D I S T R E S S}$ was estimated rather than observed. *** and ** denote significance at the $1 \%$ and $5 \%$ levels. Coefficients and standard errors shown on Price per Square Foot are $\times 10^{3}$. 
Table 7: Probit Estimation of Loan Resolution

\begin{tabular}{lccc}
\hline \hline & $(1)$ & $(2)$ & $(3)$ \\
\hline Constant & 0.03 & -0.62 & $-0.86^{*}$ \\
& $(0.43)$ & $(0.41)$ & $(0.51)$ \\
CMBS & $-0.67^{* * *}$ & $-0.56^{* *}$ & $-0.57^{* *}$ \\
& $(0.24)$ & $(0.24)$ & $(0.24)$ \\
& $-24 \%$ & $-19 \%$ & $-19 \%$ \\
Log Loan Amount & -0.074 & -0.068 & -0.077 \\
& $(0.088)$ & $(0.091)$ & $(0.093)$ \\
& $-2.7 \%$ & $-2.3 \%$ & $-2.6 \%$ \\
\hline Orig. Yr. FEs $(2005,2006$, and 2007$)$ & Yes & No & Yes \\
MSA FEs & Yes & Yes & Yes \\
Default Yr. FEs $(2008,2009,2010)$ & No & Yes & Yes \\
Number of Obs. & 175 & 175 & 175 \\
Pseudo- $R^{2}$ & $8.3 \%$ & $14.2 \%$ & $14.6 \%$ \\
\hline \hline
\end{tabular}

Notes: The table contains estimates of a probit where the dependent variable takes a value of 1 if the defaulted loan gets resolved before May 1, 2012 and 0 otherwise (equation (3) in the text). The estimates are obtained from a pooled dataset of all defaulted loans in our January 2005 to April 2012 sample. In all three specifications, the first entry for each variable is the coefficient, the second entry (in parentheses) is the robust standard error, and the third entry is the effect of a 1 unit change in the independent variable (the other characteristics are held fixed at their actual values). ***, **, and $*$ denote significance at the $1 \%, 5 \%$, and $10 \%$ levels. 

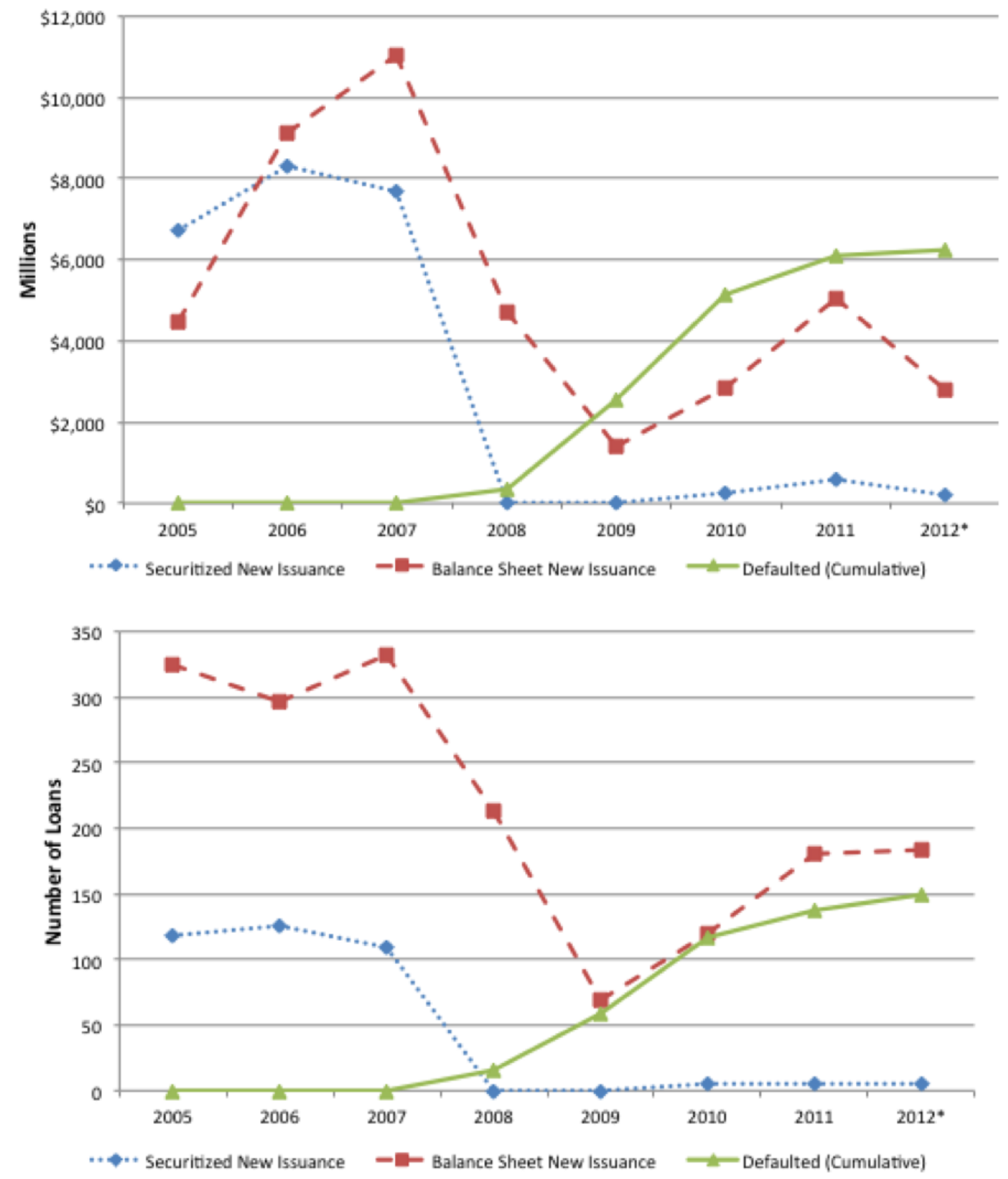

Figure 1: Issuance and defaults of loans on office property in Boston, Las Vegas, Los Angeles, and NYC Metropolitan areas originated between January 2005 and April 2012. * denotes that 2012 issuance numbers are annualized. The data consists of single-property purchase loans only. Default is defined as a completed foreclosure, a foreclosure that has been initiated but not completed, or a borrower bankruptcy. 


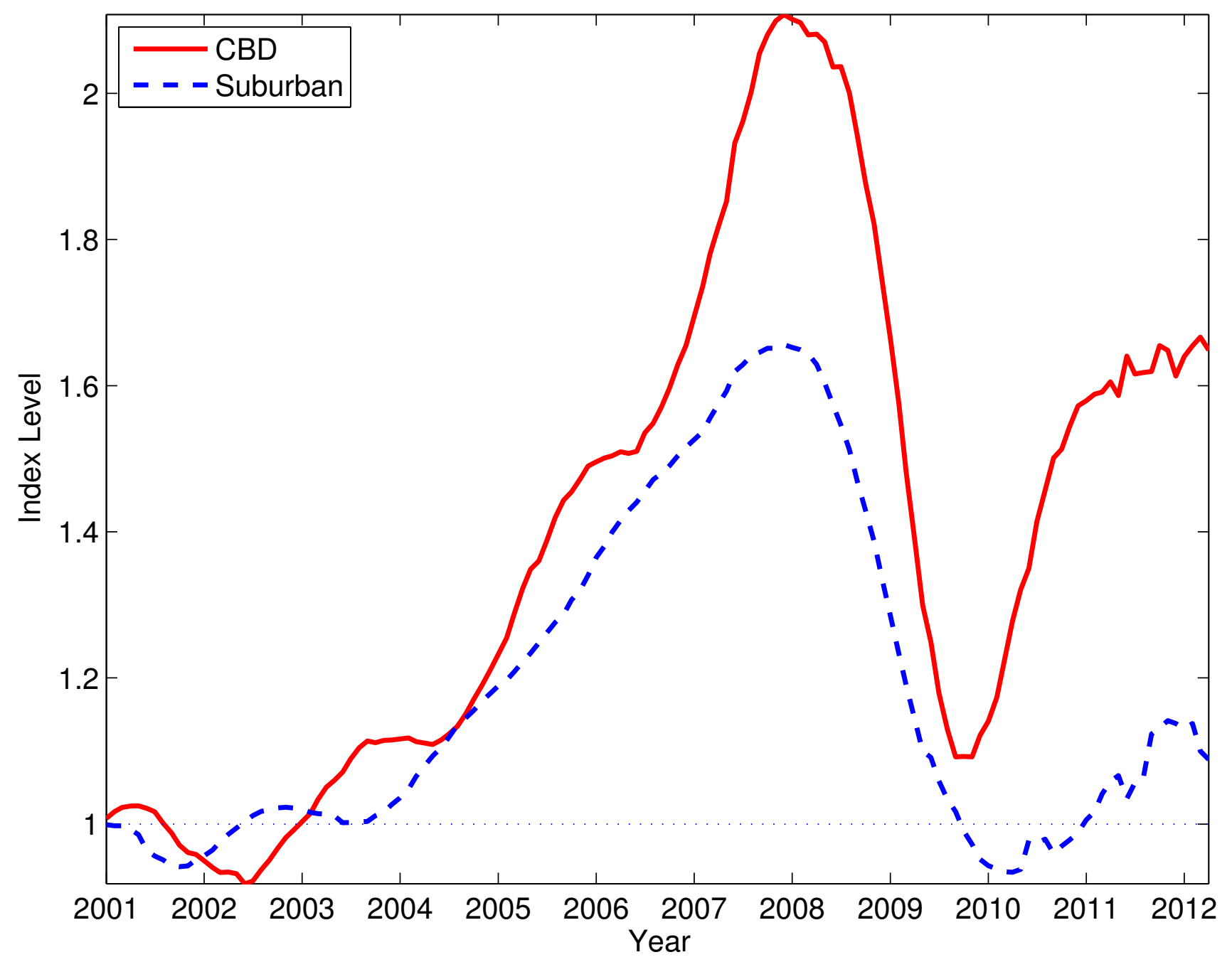

Figure 2: Office property price indices for central business district (CBD) and suburban regions from January 2001 to April 2012. The indices are Real Capital Analytics' (RCA) repeat transaction national office price series, normalized to equal 1 in January 2001. 


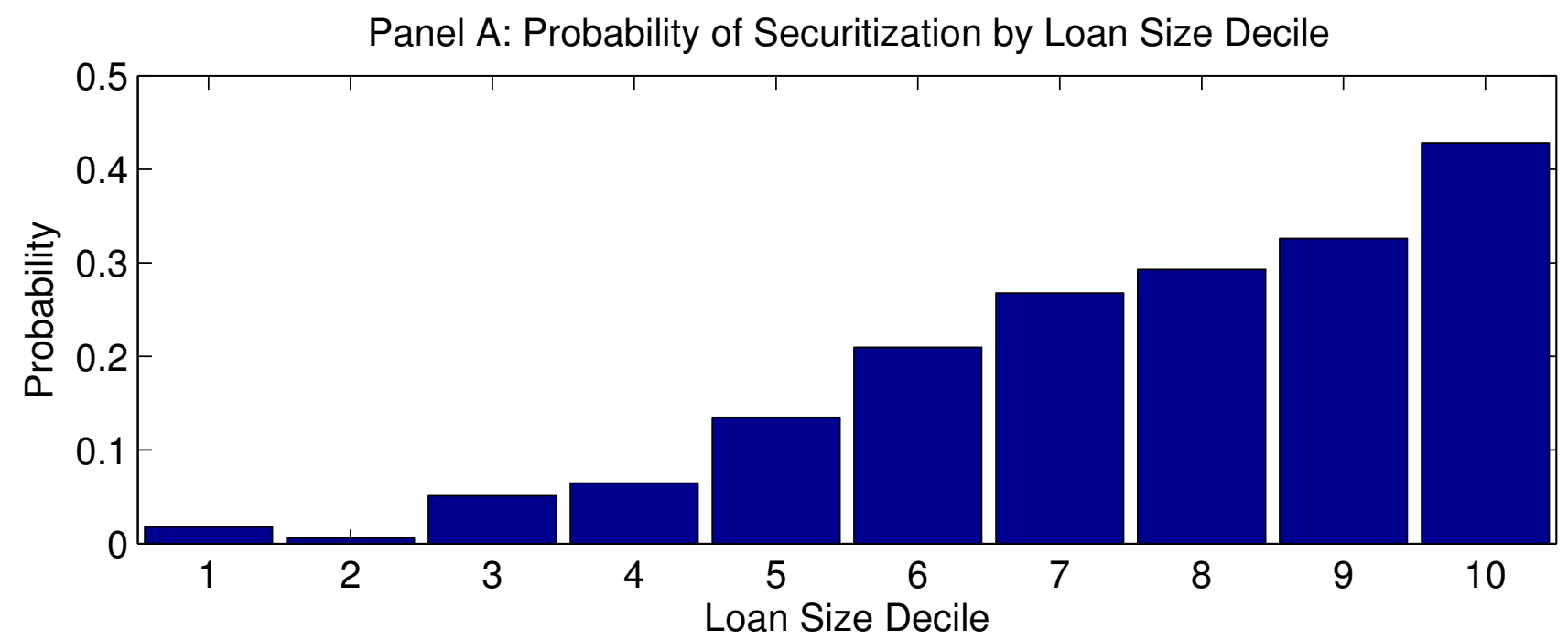

Panel B: Probit Coefficients on Loan Size Decile

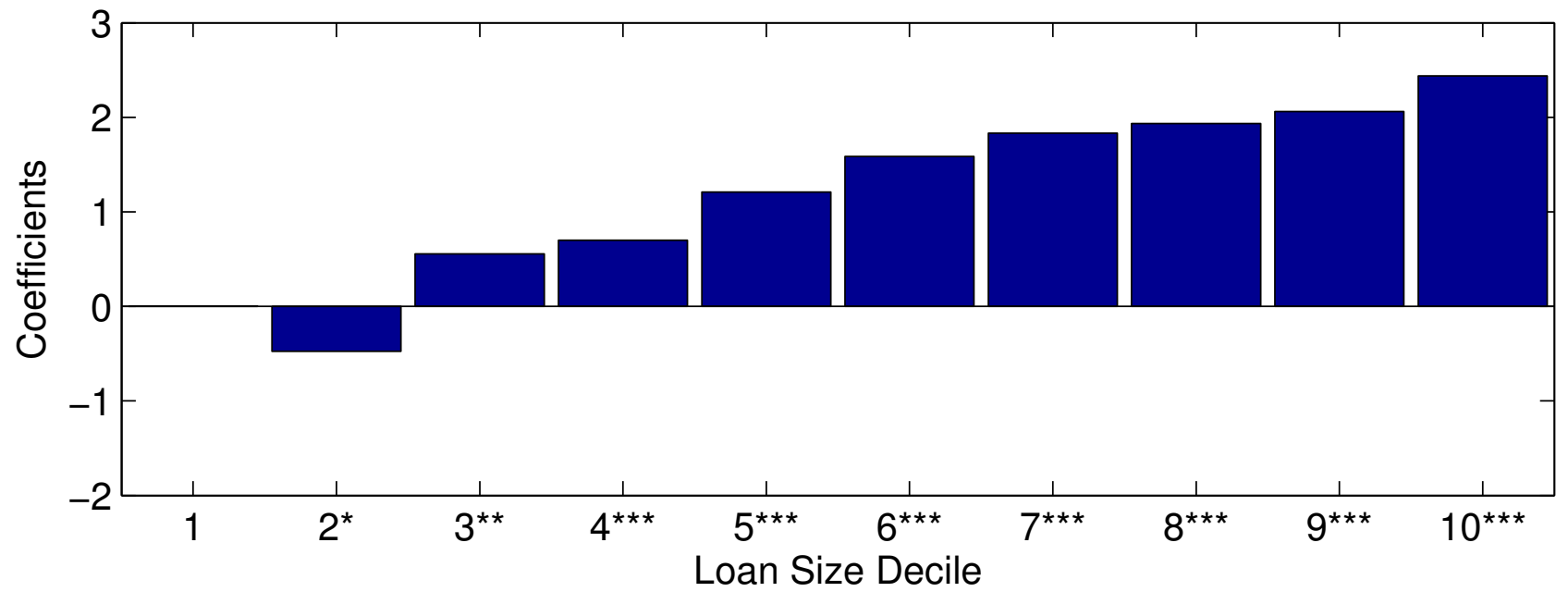

Figure 3: Probit estimates from the CMBS selection equation (equation (2)) shown in Table 3, specification 5. In Panel A, each bar shows the probability that a loan of a given size decile is securitized. The displayed probabilities are averaged over all loans. In Panel B, the probit coefficients on each loan size deciles are displayed, with the exception of decile 1. The data comprises size and securitization of office property loans in Boston, Las Vegas, Los Angeles, and NYC Metropolitan areas originated between January 2005 and April 2012.***,**, and $*$ denote significance at the $1 \%, 5 \%$, and $10 \%$ levels. 
A Appendix

A.1 Additional Empirical Results 
Table 8: Probit Estimation of Loan Securitization, Robustness

\begin{tabular}{|c|c|c|c|c|c|c|}
\hline & 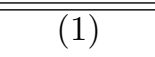 & (2) & (3) & (4) & 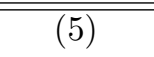 & $(6)$ \\
\hline & \multicolumn{5}{|c|}{ 2005-2007 Originations Only } & Ex. NYC \\
\hline Constant & $\begin{array}{c}-1.30^{* * *} \\
(0.22)\end{array}$ & $\begin{array}{c}-1.43^{* * *} \\
(0.23)\end{array}$ & $\begin{array}{c}-3.44^{* * *} \\
(0.48)\end{array}$ & $\begin{array}{c}-3.64^{* * *} \\
(0.45)\end{array}$ & $\begin{array}{c}0.26 \\
(0.57)\end{array}$ & $\begin{array}{c}-3.27^{* * *} \\
(0.40)\end{array}$ \\
\hline Log Loan Amount & $\begin{array}{c}0.48^{* * *} \\
(0.04) \\
12.2 \%\end{array}$ & $\begin{array}{c}0.49^{* * *} \\
(0.04) \\
12.4 \%\end{array}$ & $\begin{array}{c}0.59^{* * *} \\
(0.06) \\
12.6 \%\end{array}$ & & $\begin{array}{c}0.40^{* * *} \\
(0.07) \\
9.9 \%\end{array}$ & $\begin{array}{c}0.51^{* * *} \\
(0.06) \\
86 \%\end{array}$ \\
\hline Log Lender Assets & & & $\begin{array}{c}0.14^{* * *} \\
0.03 \\
3.0 \%\end{array}$ & $\begin{array}{c}0.22^{* * *} \\
0.03 \\
5.6 \%\end{array}$ & & \\
\hline Loan Amt./ Lender Assets & & & & $\begin{array}{c}21.10^{* *} \\
8.78 \\
544 \%\end{array}$ & & \\
\hline Development (LTV $\geq 1$ ) & $\begin{array}{c}-1.20^{* * *} \\
(0.22) \\
-30 \%\end{array}$ & $\begin{array}{c}-1.20^{* * *} \\
(0.22) \\
-30 \%\end{array}$ & $\begin{array}{c}-1.87^{* * *} \\
(0.40) \\
-35 \%\end{array}$ & $\begin{array}{c}-1.79^{* * *} \\
(0.41) \\
-48 \%\end{array}$ & $\begin{array}{c}-1.83^{* * *} \\
(0.41) \\
-45 \%\end{array}$ & $\begin{array}{c}-1.31 \text { *** } \\
(0.40) \\
-22 \%\end{array}$ \\
\hline LTV & $\begin{array}{c}-0.20 \\
(0.15) \\
-5 \%\end{array}$ & $\begin{array}{c}-0.20 \\
(0.15) \\
-5 \%\end{array}$ & $\begin{array}{c}0.13 \\
(0.28) \\
3 \%\end{array}$ & $\begin{array}{c}0.76^{* * *} \\
(0.27) \\
19 \%\end{array}$ & $\begin{array}{c}0.07 \\
(0.32) \\
2 \%\end{array}$ & $\begin{array}{c}-0.86^{* *} \\
(0.34) \\
-15 \%\end{array}$ \\
\hline Price per Square Foot & $\begin{array}{c}-0.34^{*} \\
(0.19) \\
-0.008 .5 \%\end{array}$ & $\begin{array}{c}-0.34^{*} \\
(0.19) \\
-0.0086 \%\end{array}$ & $\begin{array}{l}-0.04 \\
(0.25)\end{array}$ & $\begin{array}{c}0.19 \\
(0.22)\end{array}$ & $\begin{array}{c}0.03 \\
(0.36)\end{array}$ & $\begin{array}{c}0.24 \\
(0.42)\end{array}$ \\
\hline CBD & $\begin{array}{c}-0.68^{* * *} \\
(0.16) \\
-17 \%\end{array}$ & $\begin{array}{c}-0.69^{* * *} \\
(0.16) \\
-17 \%\end{array}$ & $\begin{array}{c}-0.75 * * * \\
(0.25) \\
-16 \%\end{array}$ & $\begin{array}{c}-0.00 \\
(0.21) \\
-0 \%\end{array}$ & $\begin{array}{c}-0.55^{* *} \\
(0.25) \\
-13 \%\end{array}$ & $\begin{array}{c}-0.37 \\
(0.23) \\
-6 \%\end{array}$ \\
\hline Multi-building & $\begin{array}{c}0.26 \\
(0.17) \\
6.5 \%\end{array}$ & $\begin{array}{c}0.25 \\
(0.17) \\
6.4 \%\end{array}$ & $\begin{array}{l}0.60^{*} \\
(0.32) \\
12.9 \%\end{array}$ & $\begin{array}{c}1.03^{* * * *} \\
(0.28) \\
26.5 \%\end{array}$ & $\begin{array}{c}0.22 \\
(0.29) \\
5.5 \%\end{array}$ & $\begin{array}{c}0.25 \\
(0.21) \\
4.3 \%\end{array}$ \\
\hline Depository US Inst. & & $\begin{array}{c}0.19^{* *} \\
0.09 \\
4.7 \%\end{array}$ & & & & \\
\hline Orig. Yr. FEs & Yes & Yes & Yes & Yes & Yes & Yes \\
\hline MSA FEs & Yes & Yes & Yes & Yes & Yes & Yes \\
\hline Prop. Age FEs $(<1960,60-80,80-00)$ & Yes & Yes & Yes & Yes & Yes & Yes \\
\hline Borrower Type FEs & Yes & Yes & Yes & Yes & Yes & Yes \\
\hline Originator FEs & No & No & No & No & Yes & No \\
\hline Number of Obs. & 1306 & 1306 & 615 & 615 & 403 & 1120 \\
\hline Pseudo- $R^{2}$ & $23 \%$ & $23 \%$ & $35 \%$ & $22 \%$ & $37 \%$ & $34 \%$ \\
\hline
\end{tabular}

Notes: The table contains estimates of a probit where the dependent variable takes a value of 1 if the loan is securitized and 0 otherwise (equation (2) in the text). In all six specifications, the first entry for each variable is the coefficient, the second entry (in parentheses) is the robust standard error, and the third entry is the effect of a 1 unit change in the independent variable (the other characteristics are held fixed at their actual values). In all specifications, we include year and MSA fixed effects. The specifications in columns 3 and 4 include only loans originated by depository US institutions and for which we have asset information on the lender in the quarter the loan is originated. The specification in column 5 includes only loans originated by the largest 10 originators that originate both balance sheet and CMBS loans in our sample. ${ }^{* * *}$ and ${ }^{* *}$ denote significance at the $1 \%$ and $5 \%$ levels. Coefficients and standard errors shown on Price per Square Foot are $\times 10^{3}$. The specifications in columns 1-5 include all loang 48 riginated 2005-2007. The specification in column 6 includes all loans originated 2005-2012 but excludes loans on NYC property. 
Table 9: Alternative Definitions of Development Loan

\begin{tabular}{|c|c|c|c|c|c|}
\hline & $(1)$ & $(2)$ & $(3)$ & $(4)$ & $(5)$ \\
\hline Constant & $\begin{array}{c}-2.78^{* * *} \\
(0.23)\end{array}$ & $\begin{array}{c}-2.72^{* * *} \\
(0.23)\end{array}$ & $\begin{array}{c}-2.66^{* * *} \\
(0.24)\end{array}$ & $\begin{array}{c}-2.56^{* * *} \\
(0.24)\end{array}$ & $\begin{array}{c}-2.50^{* * *} \\
(0.24)\end{array}$ \\
\hline Log Loan Amount & $\begin{array}{c}0.48^{* * *} \\
(0.04)\end{array}$ & $\begin{array}{c}0.48^{* * *} \\
(0.04)\end{array}$ & $\begin{array}{c}0.48^{* * *} \\
(0.04)\end{array}$ & $\begin{array}{c}0.48^{* * * *} \\
(0.04)\end{array}$ & $\begin{array}{c}0.52^{* * *} * \\
(0.04)\end{array}$ \\
\hline Development (LTV $>=1$, benchmark) & $\begin{array}{c}-1.19^{* * *} \\
(0.21)\end{array}$ & & & & \\
\hline Development (LTV>=1.05) & & $\begin{array}{c}-1.06^{* * *} \\
(0.25)\end{array}$ & & & \\
\hline Development $(\mathrm{LTV}>=1.1)$ & & & $\begin{array}{c}-1.01^{* * *} \\
(0.28)\end{array}$ & & \\
\hline Development (LTV>=1.15) & & & & $\begin{array}{c}-0.75^{* * *} \\
(0.29)\end{array}$ & \\
\hline Development (Stated Borrower Objective) & & & & & $\begin{array}{c}-0.90^{* * *} \\
(0.16)\end{array}$ \\
\hline LTV & $\begin{array}{l}-0.21 \\
(0.15)\end{array}$ & $\begin{array}{c}-0.36^{* *} \\
(0.17)\end{array}$ & $\begin{array}{c}-0.45^{* * *} \\
(0.18)\end{array}$ & $\begin{array}{c}-0.61^{* * *} \\
(0.18)\end{array}$ & $\begin{array}{c}-0.82^{* * *} \\
(0.15)\end{array}$ \\
\hline Price per Square Foot & $\begin{array}{c}-0.39^{* *} \\
(0.18)\end{array}$ & $\begin{array}{c}-0.41^{* *} \\
(0.18)\end{array}$ & $\begin{array}{c}-0.43^{* *} \\
(0.18)\end{array}$ & $\begin{array}{c}-0.44^{* *} \\
(0.18)\end{array}$ & $\begin{array}{c}-0.48^{* *} \\
(0.20)\end{array}$ \\
\hline $\mathrm{CBD}$ & $\begin{array}{c}-0.65 * * * \\
(0.15)\end{array}$ & $\begin{array}{c}-0.66^{* * *} \\
(0.15)\end{array}$ & $\begin{array}{c}-0.65 * * * \\
(0.15)\end{array}$ & $\begin{array}{c}-0.66^{* * *} \\
(0.15)\end{array}$ & $\begin{array}{c}-0.67 * * * \\
(0.15)\end{array}$ \\
\hline Multi-building & $\begin{array}{c}0.26 \\
(0.16) \\
\end{array}$ & $\begin{array}{c}0.23 \\
(0.16) \\
\end{array}$ & $\begin{array}{c}0.23 \\
(0.15) \\
\end{array}$ & $\begin{array}{c}0.23 \\
(0.15) \\
\end{array}$ & $\begin{array}{c}0.21 \\
(0.16) \\
\end{array}$ \\
\hline Orig. Yr. FEs & Yes & Yes & Yes & Yes & Yes \\
\hline MSA FEs & Yes & Yes & Yes & Yes & Yes \\
\hline Prop. Age FEs & Yes & Yes & Yes & Yes & Yes \\
\hline Borrower Type FEs & Yes & Yes & Yes & Yes & Yes \\
\hline Number of Obs. & 1,962 & 1,962 & 1,962 & 1,962 & 1,962 \\
\hline Pseudo- $R^{2}$ & 0.32 & 0.32 & 0.31 & 0.31 & 0.33 \\
\hline
\end{tabular}

Notes: The table contains estimates of a probit where the dependent variable takes a value of 1 if the loan is securitized and 0 otherwise (equation (2) in the text). In all specifications, the first entry for each variable is the coefficient and the second entry (in parentheses) is the robust standard error. In all specifications, we include year and MSA fixed effects. The specification in column 5 defines a development loan as one for which the borrower states its intention as "Redevelopment" or "Renovation" rather than one of the other options ("Investment", "Occupancy", or "Condo Conversion"). *** and ** denote significance at the $1 \%$ and $5 \%$ levels. Coefficients and standard errors shown on Price per Square Foot are $\times 10^{3}$. 
Table 10: Probit Estimation of Loan Securitization from Structural Model, Loans Originated by Non-Depository Institutions

\begin{tabular}{|c|c|c|c|c|c|c|}
\hline & (1) & $(2)$ & $(3)$ & $(4)$ & $(5)$ & $(6)$ \\
\hline & \multicolumn{3}{|c|}{ Full Sample } & \multicolumn{3}{|c|}{ Non-Depository } \\
\hline & $\alpha=1$ & $\alpha=0.9$ & $\alpha=0.8$ & $\alpha=1$ & $\alpha=0.9$ & $\alpha=0.8$ \\
\hline Constant & $\begin{array}{c}-3.00^{* * *} \\
(0.25)\end{array}$ & $\begin{array}{c}-3.01^{* * *} \\
(0.25)\end{array}$ & $\begin{array}{c}-3.01^{* * *} \\
(0.25)\end{array}$ & $\begin{array}{c}-4.23^{* *} \\
(1.81)\end{array}$ & $\begin{array}{c}-4.23^{* *} \\
(1.81)\end{array}$ & $\begin{array}{c}-4.23^{* *} \\
(1.81)\end{array}$ \\
\hline Log Loan Amount & $\begin{array}{c}0.50^{* * * *} \\
(0.04)\end{array}$ & $\begin{array}{c}0.50^{* * *} \\
(0.04)\end{array}$ & $\begin{array}{c}0.50^{* * *} \\
(0.04)\end{array}$ & $\begin{array}{c}0.34^{* * *} \\
(0.07)\end{array}$ & $\begin{array}{c}0.34^{* * *} \\
(0.07)\end{array}$ & $\begin{array}{c}0.34^{* * *} \\
(0.07)\end{array}$ \\
\hline Development (LTV $\geq 1)$ & $\begin{array}{c}-1.22^{* * *} \\
(0.25)\end{array}$ & $\begin{array}{c}-1.23^{* * *} \\
(0.25)\end{array}$ & $\begin{array}{c}-1.23^{* * *} \\
(0.25)\end{array}$ & $\begin{array}{c}-0.92^{* *} \\
(0.38)\end{array}$ & $\begin{array}{c}-0.92^{* *} \\
(0.38)\end{array}$ & $\begin{array}{c}-0.93^{* *} \\
(0.39)\end{array}$ \\
\hline LTV & $\begin{array}{l}-0.23 \\
(0.15)\end{array}$ & $\begin{array}{l}-0.23 \\
(0.15)\end{array}$ & $\begin{array}{l}-0.22 \\
(0.15)\end{array}$ & $\begin{array}{l}-0.47 \\
(0.32)\end{array}$ & $\begin{array}{l}-0.47 \\
(0.32)\end{array}$ & $\begin{array}{l}-0.46 \\
(0.32)\end{array}$ \\
\hline Price per Square Foot & $\begin{array}{c}-0.42^{* *} \\
(0.19)\end{array}$ & $\begin{array}{c}-0.43^{* *} \\
(0.19)\end{array}$ & $\begin{array}{c}-0.43^{* *} \\
(0.19)\end{array}$ & $\begin{array}{l}-0.39 \\
(0.37)\end{array}$ & $\begin{array}{l}-0.40 \\
(0.38)\end{array}$ & $\begin{array}{l}-0.41 \\
(0.38)\end{array}$ \\
\hline $\mathrm{CBD}$ & $\begin{array}{c}-0.67^{* * *} \\
(0.16)\end{array}$ & $\begin{array}{c}-0.67^{* * *} \\
(0.16)\end{array}$ & $\begin{array}{c}-0.67^{* * *} \\
(0.16)\end{array}$ & $\begin{array}{l}-0.37 \\
(0.30)\end{array}$ & $\begin{array}{l}-0.37 \\
(0.31)\end{array}$ & $\begin{array}{l}-0.36 \\
(0.31)\end{array}$ \\
\hline Multi-building & $\begin{array}{c}0.25 \\
(0.16)\end{array}$ & $\begin{array}{c}0.25 \\
(0.16)\end{array}$ & $\begin{array}{c}0.25 \\
(0.16)\end{array}$ & $\begin{array}{c}0.12 \\
(0.36)\end{array}$ & $\begin{array}{c}0.12 \\
(0.36)\end{array}$ & $\begin{array}{c}0.12 \\
(0.36)\end{array}$ \\
\hline Depository US Inst. & $\begin{array}{c}0.22^{* * *} \\
(0.08)\end{array}$ & $\begin{array}{c}0.22^{* * *} \\
(0.08)\end{array}$ & $\begin{array}{c}0.22^{* * *} \\
(0.08)\end{array}$ & & & \\
\hline$\hat{\varepsilon}_{i, t}^{D I S T R E S S}$ & $\begin{array}{c}0.0368 \\
(0.0706) \\
\end{array}$ & $\begin{array}{l}-0.0017 \\
(0.0735) \\
\end{array}$ & $\begin{array}{c}-0.0483 \\
(0.0768) \\
\end{array}$ & $\begin{array}{c}-0.0598 \\
(0.1590) \\
\end{array}$ & $\begin{array}{c}-0.1150 \\
(0.2936) \\
\end{array}$ & $\begin{array}{c}-0.1905 \\
(0.6382) \\
\end{array}$ \\
\hline Orig. Yr. FEs $(2005,2006$, and 2007) & Yes & Yes & Yes & Yes & Yes & Yes \\
\hline MSA FEs & Yes & Yes & Yes & Yes & Yes & Yes \\
\hline Prop. Age FEs $(<1960,60-80,80-00)$ & Yes & Yes & Yes & Yes & Yes & Yes \\
\hline Borrower Type FEs & Yes & Yes & Yes & Yes & Yes & Yes \\
\hline Number of Obs. & 1962 & 1962 & 1962 & 652 & 652 & 652 \\
\hline Pseudo- $R^{2}$ & $34 \%$ & $34 \%$ & $34 \%$ & $32 \%$ & $32 \%$ & $33 \%$ \\
\hline
\end{tabular}

Notes: The table contains estimates of a probit where the dependent variable takes a value of 1 if the loan is securitized and 0 otherwise (equation (3) in the text). The independent variables $x_{i, t-1}$ are the same as in Table 3 . We identify the distress variable $\varepsilon_{i, t}^{\text {DISTRESS }}$ using default rates of the loans (see section 4) under the assumptions about the value of $\alpha$ stated. The assumption that $\alpha=1$ corresponds to no difference in the likelihood of distressed CMBS loans entering into default relative to balance sheet loans. Values of $\alpha<1$ imply that distressed CMBS loans are more likely to default than distressed balance sheet loans. The estimates are obtained from a pooled dataset of all loans in our January 2005 to April 2012 sample. In all specifications, the first entry for each variable is the coefficient and the second entry (in parentheses) is the robust standard error. Standard errors are estimated using nonparametric bootstrap with 500 replications to take into account the fact that $\varepsilon_{i, t}^{D I S T R E S S}$ was estimated rather than observed. *** and ** denote significance at the $1 \%$ and $5 \%$ levels. Coefficients and standard errors shown on Price per Square Foot are $\times 10^{3}$. 


\section{A.2 Estimation Details}

We have the index model:

$$
\begin{aligned}
\operatorname{Pr}\left(D_{i, t+1}=1\right) & =\left(C M B S_{i, t}+\alpha\left(1-C M B S_{i, t}\right)\right) \operatorname{Pr}\left(\tilde{x}_{i, t-1} \eta+\varepsilon_{i, t+1}^{\text {DISTESS }}>0\right) \\
& =\left(C M B S_{i, t-1}+\alpha\left(1-C M B S_{i, t-1}\right)\right) F\left(\tilde{x}_{i, t-1} \eta\right) .
\end{aligned}
$$

assuming that $\varepsilon_{i, t+1}^{D I S T R E S S}$ has a symmetric cumulative distribution function $F(\cdot)$.

The density of $D_{i, t+1}$ given $\tilde{x}_{i, t-1}, \eta, \alpha$, and $C M B S_{i, t}$ is thus

$f\left(D_{i, t+1} \mid \tilde{x}_{i, t-1}, \eta, \alpha\right)=\left\{\begin{array}{c}{\left[F\left(\tilde{x}_{i, t-1} \eta\right)\right]^{D_{i, t+1}}\left[1-F\left(\tilde{x}_{i, t-1} \eta\right)\right]^{1-D_{i, t+1}} C M B S_{i, t}} \\ {\left[\alpha F\left(\tilde{x}_{i, t-1} \eta\right)\right]^{D_{i, t+1}}\left[1-\alpha F\left(\tilde{x}_{i, t-1} \eta\right)\right]^{1-D_{i, t+1}}\left(1-C M B S_{i, t}\right)}\end{array}\right\}$

so the log likelihood of observation $i$ is

$$
\begin{aligned}
\ell_{i}(\eta)= & D_{i, t+1} \ln \left\{\left[C M B S_{i, t}+\alpha\left(1-C M B S_{i, t}\right)\right] F\left(\tilde{x}_{i, t-1} \eta\right)\right\} \\
& +\left(1-D_{i, t+1}\right) \ln \left\{1-\left[C M B S_{i, t}+\alpha\left(1-C M B S_{i, t}\right)\right] F\left(\tilde{x}_{i, t-1} \eta\right)\right\}
\end{aligned}
$$

and grouping observations by their securitization status we can write the log likelihood for the sample as

$$
\begin{aligned}
\mathcal{L}(\eta)= & \sum_{i=1}^{N_{C M B S}}\left\{D_{i, t+1} \ln F\left(\tilde{x}_{i, t-1} \eta\right)+\left(1-D_{i, t+1}\right) \ln \left(1-F\left(\tilde{x}_{i, t-1} \eta\right)\right)\right\} \\
& +\sum_{i=1}^{N_{B A L . S H E E T}}\left\{D_{i, t+1} \ln \left[\alpha F\left(\tilde{x}_{i, t-1} \eta\right)\right]+\left(1-D_{i, t+1}\right) \ln \left(1-\alpha F\left(\tilde{x}_{i, t-1} \eta\right)\right)\right\}
\end{aligned}
$$

which can be estimated using maximum likelihood.

We can thus take $\hat{\varepsilon}_{i, t+1}^{D I S T R E S S}$ as an estimate of $\varepsilon_{i, t}^{D I S T R E S S}$ to estimate (3). We follow Chesher and Irish (1987) in computing the generalized residuals as the derivative 
of the log-likelihood of each observation with respect to the constant term, i.e.,

$$
\begin{aligned}
& \hat{\varepsilon}_{i, t+1}=E\left(\varepsilon_{i, t+1}^{D I S T R E S S} \mid D_{i, t+1}, \tilde{x}_{i, t-1}, \eta, \alpha, C M B S_{i, t}\right) \\
& =\frac{\partial \ell_{i}(\eta)}{\partial \eta} \\
& =\left\{\begin{array}{c}
\frac{D_{i, t+1} f\left(\tilde{x}_{i, t-1} \eta\right)}{F\left(\tilde{x}_{i, t-1} \eta\right)}+\frac{-\left(1-D_{i, t+1}\right) f\left(\tilde{x}_{i, t-1} \eta\right)}{1-F\left(\tilde{x}_{i, t-1} \eta\right)} C M B S_{i, t} \\
\frac{D_{i, t+1} f\left(\tilde{x}_{i, t-1} \eta\right)}{F\left(\tilde{x}_{i, t-1} \eta\right)}+\frac{-\left(1-D_{i, t+1}\right) \alpha f\left(\tilde{x}_{i, t-1} \eta\right)}{1-\alpha F\left(\tilde{x}_{i, t-1} \eta\right)}\left(1-C M B S_{i, t}\right)
\end{array}\right\} \\
& =\left\{\begin{array}{c}
\frac{\left(D_{i, t+1}-F\left(\tilde{x}_{i, t-1} \eta\right)\right) f\left(\tilde{x}_{i, t-1} \eta\right)}{F\left(\tilde{x}_{i, t-1} \eta\right)\left[1-F\left(\tilde{x}_{i, t-1} \eta\right)\right]} C M B S_{i, t} \\
\frac{\left(D_{i, t+1}-\alpha F\left(\tilde{x}_{i, t-1} \eta\right)\right) f\left(\tilde{x}_{i, t-1} \eta\right)}{F\left(\tilde{x}_{i, t-1} \eta\right)\left[1-\alpha F\left(\tilde{x}_{i, t-1} \eta\right)\right]}\left(1-C M B S_{i, t}\right)
\end{array}\right\}
\end{aligned}
$$

See also Cox and Snell (1968), Pagan and Vella (1989), and Greene (2000, pp. 916917) for discussions of generalized residuals. Intuitively, the effect of $\alpha$ in (8) is to increase the residual for balance sheet loans that do not default. If $\alpha<1$, the balance sheet loans had on average higher risk than what we observe purely from the default and the factor $\alpha$ corrects accordingly. 


\section{References}

Acharya, V. V.; P. Schnabl; and G. Suarez. "Securitization without Risk Transfer." Journal of Financial Economics 107:3 (2013), 515-536.

Adelino, M.; K. Gerardi; and P. S. Willen. "Why Don't Lenders Renegotiate More Home Mortgages? Redefaults, Self-Cures and Securitization." Journal of Monetary Economics 60:7 (2013), 835-853.

Adelino, M.; A. Schoar; and F. Severino. "Credit Supply and House Prices: Evidence from Mortgage Market Segmentation." NBER Working Paper 17832 (2012).

Agarwal, S.; G. Amromin; I. Ben-David; S. Chomsisengphet; and D. D. Evanoff. "The Role of Securitization in Mortgage Renegotiation." Journal of Financial Economics 102:3 (2011), 559-578.

Agarwal, S.; Y. Chang; and A. Yavas. "Adverse Selection in Mortgage Securitization." Journal of Financial Economics 105:3 (2012), 640-660.

Ambrose, B. W.; M. Lacour-Little; and A. B. Sanders. "Does Regulatory Capital Arbitrage, Reputation, or Asymmetric Information Drive Securitization?" Journal of Financial Services Research 28 (2005), 113-133.

Ambrose, B. W., and A. B. Sanders. "Commercial Mortgage-Backed Securities: Prepayment and Default." Journal of Real Estate Finance and Economics 26:2/3 (2003), 179-196.

Ambrose, B. W.; A. B. Sanders; and A. Yavas. "Servicers and Mortgage-Backed Securities Default:Theory and Evidence." Real Estate Economics (forthcoming). 
An, X.; Y. Deng; and S. A. Gabriel. "Asymmetric Information, Adverse Selection, and the Pricing of CMBS." Journal of Financial Economics 100:2 (2011), 304-325.

Benmelech, E.; J. Dlugosz; and V. Ivashina. "Securitization without Adverse Selection: The Case of CLOs." Journal of Financial Economics 106:1 (2012), 91-113.

Bubb, R., and A. Kaufman. "Securitization and Moral Hazard: Evidence from Credit Scoring Cutoff Rules." Journal of Monetary Economics 63 (2014), 1-18.

Calem, P.; F. Covas; and J. Wu. "The Impact of the 2007 Liquidity Shock on Bank Jumbo Mortgage Lending." Journal of Money, Credit and Banking S45:1 (2013), 5991.

Case, K., and R. J. Shiller. "The Efficiency of the Market for Single-family Homes." American Economic Review 79:1 (1989), 125-137.

Chesher, A., and M. Irish. "Residual Analysis in the Grouped and Censored Normal Linear Model." Journal of Econometrics 34 (1987), 33-61.

Cordell, L.; K. Dynan; A. Lehnert; N. Liang; and E. Mauskopf. "The Incentives of Mortgage Servicers: Myths and Realities." Uniform Commercial Code Law Journal 41 (2009), 347-74.

Cox, D. R., and E. J. Snell. "A General Definition of Residuals." Journal of the Royal Statistical Society. Series B 30:2 (1968), 248-275.

Deng, Y.; J. Quigley; and R. Van Order. "Mortgage Terminations, Heterogeneity, and the Exercise of Mortgage Options." Econometrica 68:2 (2000), 275-307.

Diamond, D. W. "Financial Intermediation and Delegated Monitoring." Review of Economic Studies 51:3 (1984), 393-414. 
Dierker, M.; D. Quan; and W. Torous. "Valuing the Defeasance Option in Securitized Commercial Mortgages." Real Estate Economics 33:4 (2005), 663-680.

Downing, C.; D. Jaffee; and N. Wallace. "Is the Market for Mortgage-Backed Securities a Market for Lemons?" Review of Financial Studies 22:7 (2009), 2257-2294.

Federal Reserve Board of Governors. Consumer Credit - G. 19. Historical Data (2012). Available at

http://www.federalreserve.gov/releases/G19/HIST/cc_hist_mh_levels.html.

Flavin, M., and T. Yamashita. "Owner-Occupied Housing and the Composition of the Household Portfolio." American Economic Review 92:1 (2002), 345-362.

Frehen, R. K.; G. Rouwenhorst; and W. N. Goetzmann. "Dutch Securities for American Land Speculation in the Late-Eighteenth Century." Working Paper, Yale University (2012).

Fuster, A., and J. Vickery. "Securitization and the Fixed-Rate Mortgage." Review of Financial Studies 28:1 (2015), 176-211.

Gan, Y. H., and C. Mayer. "Agency Conflicts, Asset Substitution, and Securitization." Working Paper, Columbia University (2007).

Ghent, A. C. "Securitization and Mortgage Renegotiation: Evidence from the Great Depression." Review of Financial Studies 24:6 (2011), 1814-1847.

Giambona, E.; A. Mello; and T. Riddiough. "Collateral and the Limits of Debt Capacity: Theory and Evidence." Working Paper, University of Wisconsin (2012).

Goetzmann, W. N. "The Single Family Home in the Investment Portfolio." Journal of Real Estate Finance and Economics 6 (1993), 201-222. 
Goetzmann, W. N., and F. Newman. "Securitization in the 1920s." NBER Working Paper 15650 (2010).

Greene, W. H. Econometric Analysis, 4th ed. Upper Saddle River: Prentice-Hall: Upper Saddle River (2000).

Hartman-Glaser, B.; T. Piskorski; and A. Tchistyi. "Optimal Securitization with Moral Hazard." Journal of Financial Economics 104:1 (2012), 186-202.

Jiang, W.; A. Nelson; and E. Vytlacil. "Securitization and Loan Performance: Ex Ante and Ex Post Relations in the Mortgage Market." Review of Financial Studies 27:2 (2014), 454-483.

Keys, B.; T. Mukherjee; A. Seru; and V. Vig. "Did Securitization Lead to Lax Screening? Evidence From Subprime Loans." Quarterly Journal of Economics 125 (2010), 307-362.

Krainer, J., and E. Laderman. "Mortgage Loan Securitization and Relative Loan Performance." Journal of Financial Services Research 45 (2014), 39-66.

Loutskina, E. "The Role of Securitization in Bank Liquidity and Funding Management." Journal of Financial Economics 100 (2011), 663-684.

Loutskina, E., and P. E. Strahan. "Securitization and the Declining Impact of Bank Finance on Loan Supply: Evidence from Mortgage Originations." Journal of Finance 44:2 (2009), 861-889.

Loutskina, E., and P. E. Strahan. "Informed and Uninformed Investment in Housing: The Downside of Diversification." Review of Financial Studies 24:5 (2011), 1447-1480. 
Pagan, A. "Econometric Issues in the Analysis of Regressions with Generated Regressors." International Economic Review 25:1 (1984), 221-247.

Pagan, A., and F. Vella. "Diagnostic Tests for Models Based on Individual Data: A Survey." Journal of Applied Econometrics 4 (1989), S29-S59.

Piskorski, T.; A. Seru; and V. Vig. "Securitization and Distressed Loan Renegotiation: Evidence from the Subprime Mortgage Crisis." Journal of Financial Economics 97 (2010), 369-397.

Riddiough, T. J., and H. E. Thompson. "Déjà Vu All Over Again: Agency, Uncertainty, Leverage and the Panic of 1857." Working Paper, University of Wisconsin (Madison) (2011).

Shumway, T. "Forecasting Bankruptcy More Accurately: A Simple Hazard Model." Journal of Business 74:1 (2001), 101-124.

Snowden, K. A. "Covered Farm Mortgage Bonds in the United States During the Late Nineteenth Century." Journal of Economic History 70:4 (2010), 783-812.

Stanton, R., and N. Wallace. "CMBS Subordination, Ratings Inflation, and Regulatory Capital Arbitrage." Working Paper, University of California (Berkeley) (2012).

Titman, S., and S. Tsyplakov. "Originator Performance, CMBS Structures, and the Risk of Commercial Mortgages." Review of Financial Studies 23:9 (2010), 35583594. 